\title{
An ecosystem approach to assess soil quality in organically and conventionally managed farms in Iceland and Austria
}

\author{
J. P. van Leeuwen ${ }^{1}$, T. Lehtinen ${ }^{2,3,4}$, G. J. Lair ${ }^{3,5}$, J. Bloem ${ }^{6}$, L. Hemerik ${ }^{1}$, K. V. Ragnarsdóttir ${ }^{4}$, \\ G. Gísladóttir ${ }^{2}$, J. S. Newton ${ }^{7}$, and P. C. de Ruiter ${ }^{1}$ \\ ${ }^{1}$ Biometris, Wageningen University, P.O. Box 100, 6700 AC Wageningen, the Netherlands \\ ${ }^{2}$ Institute of Life and Environmental Sciences, University of Iceland, Sturlugata 7, IS-101 Reykjavík, Iceland \\ ${ }^{3}$ Institute of Soil Research, University of Natural Resources and Life Sciences (BOKU), \\ Peter-Jordan-Straße 82, 1190 Vienna, Austria \\ ${ }^{4}$ Institute of Earth Sciences, University of Iceland, Sturlugata 7, IS-101 Reykjavík, Iceland \\ ${ }^{5}$ Institute of Ecology, University of Innsbruck, Sternwartestrasse 15, 6020 Innsbruck, Austria \\ ${ }^{6}$ Alterra, Wageningen University and Research Centre, P.O. Box 47, 6700 AA Wageningen, the Netherlands \\ ${ }^{7}$ Department of Biological Sciences, University of Alberta, CW 405, Edmonton T6G 2E9, Alberta, Canada
}

Correspondence to: J. P. van Leeuwen (jeroen.vanleeuwen@wur.nl)

Received: 12 June 2014 - Published in SOIL Discuss.: 24 June 2014

Revised: - - Accepted: 17 October 2014 - Published: 6 January 2015

\begin{abstract}
Intensive agricultural production can be an important driver for the loss of long-term soil quality. For this reason, the European Critical Zone Observatory $(\mathrm{CZO})$ network adopted four pairs of agricultural CZO sites that differ in their management: conventional or organic. The CZO sites include two pairs of grassland farms in Iceland and two pairs of arable farms in Austria. Conventional fields differed from the organic fields in the use of artificial fertilisers and pesticides.

Soils of these eight farms were analysed in terms of their physical, chemical, and biological properties, including soil aggregate size distribution, soil organic matter contents, abundance of soil microbes and soil fauna, and taxonomic diversity of soil microarthropods.

In Icelandic grasslands, organically farmed soils had larger mean weight diameters of soil aggregates than the conventional farms, while there were no differences on the Austrian farms. Organic farming did not systematically influence organic matter contents or composition, nor soil carbon and nitrogen contents. Also, soil food web structures, in terms of presence of trophic groups of soil organisms, were highly similar among all farms, indicating a low sensitivity of trophic structure to land use or climate. However, soil organism biomass, especially of bacteria and nematodes, was consistently higher on organic farms than on conventional farms. Within the microarthropods, taxonomic diversity was systematically higher in the organic farms compared to the conventional farms. This difference was found across countries and farm, crop, and soil types. The results do not show systematic differences in physical and chemical properties between organic and conventional farms, but confirm that organic farming can enhance soil biomass and that microarthropod diversity is a sensitive and consistent indicator for land management.
\end{abstract}




\section{Introduction}

Soil is considered to be one of the most important natural resources for life on Earth. Soil processes govern a wide array of ecosystem services, such as the provision of food, feed and fibre, carbon sequestration, hydrological regulation, and contaminant attenuation (Costanza et al., 1997).

Mostly due to human activities, soil quality, here defined in terms of the soil's ability to deliver ecosystem services, is being drastically reduced in many locations worldwide (Vitousek, 1997). Global loss of soil ecosystem services is due to many different environmental threats, such as climate change, intensive agricultural production, and environmental pollution.

In order to come up with effective strategies to protect and enhance soil quality, the Critical Zone Observatory (CZO) network was established across the USA and Europe (Anderson et al., 2008). The CZO network is an internationally coordinated interdisciplinary research effort to better understand the chemical, physical and biological processes that shape the Earth's surface and support the terrestrial life on the planet.

As part of the CZO research effort, the European Commission has provided funding for a large multi-disciplinary research project: Soil Transformations in European Catchments (SoilTrEC). This project aims to understand and quantify the physical, chemical, and biological processes that are critical to soil ecosystem functions and services in the European CZOs (Bernasconi et al., 2011; Menon et al., 2014).

The European CZO network consists of sites along soil formation gradients (Austria, Switzerland, Iceland), along a soil degradation gradient (Greece), along a pollution gradient (Czech Republic), and of agricultural sites differing in methods of soil management (Austria, Iceland) (Menon et al., 2014; Banwart et al., 2011).

This paper presents the soil quality assessment as carried out for the agricultural CZO sites in Europe. The agricultural sites have been chosen as part of the CZO network because intensive agricultural production is an important driver of loss in soil quality, e.g. due to decreased organic matter contents. Intensive agriculture may also cause environmental problems, e.g. nitrate leaching to nearby natural ecosystems, and pesticide contamination of surface and groundwater (Skinner et al., 1997). The agricultural CZO sites consist, in total, of eight farms: four grassland farms in Iceland, of which two are conventional and two organic, and four arable farms in Austria, of which two are conventional and two organic. The organic farms differed from the conventional farms in that only organic fertilisers were applied and no pesticides were used. On the conventional grassland farms in Iceland, some organic fertilisation was used in addition to the artificial inorganic fertilisers. On the conventional arable farms in Austria, only artificial inorganic fertilisers were applied together with pesticides. The central idea behind the organic farming practice is that the community of soil organisms will become more important in terms of delivering important soil ecosystem functions, especially in terms of soil structure formation, soil carbon dynamics, and nutrient mineralisation, as well as the suppression of soil-borne diseases (Birkhofer et al., 2008). The present study investigates biological, physical, and chemical soil quality parameters, focused on soil structure formation, soil organic matter dynamics and nutrient cycling, and the soil as a habitat for species-rich communities.

Soil structure is an important attribute of soil quality. Soil aggregates and the pores between the aggregates provide space, water, and oxygen, thereby creating habitats for a large diversity in soil organisms (Anderson, 1978; Sulkava and Huhta, 1998). Soil organisms play an important twofold role in determining soil structure formation. Firstly, microorganisms produce exudates (polysaccharides) that enhance aggregation of soil particles, and fungal hyphae also physically bind soil particles (de Gryze et al., 2005; Wright et al., 2007; Tisdall and Oades, 1982). Secondly, the soil fauna plays a role in creating a stable soil pore structure through moving in the soil and the formation of faecal pellets (Oades, 1993; Lee and Foster, 1991; Jastrow and Miller, 1991; Lavelle et al., 2006). Furthermore, soil structure is strongly linked to soil organic matter (SOM) dynamics, as incorporation of SOM into the soil aggregates "protects" it from microbial decomposition, thereby stabilising SOM content and sequestering carbon in the soil, with potentially positive effects on plant productivity (Golchin et al., 1994).

Soil organic matter is an essential component of soil quality, governing processes like carbon sequestration, nutrient cycling, water retention, and soil aggregate turnover. Soil organic matter dynamics are driven by land use through root turnover, deposition of plant residues, and decomposition by the soil microbial populations. Soil organisms are known to play important roles in SOM dynamics (Wardle et al., 2004; de Ruiter et al., 1994; Lavelle et al., 2006) by decomposing SOM. This process mineralises carbon (C) and nutrients like nitrogen $(\mathrm{N})$, making these available for plant uptake. To understand the role of soil organisms in decomposition processes, SOM has been defined in terms of fractions based on decomposability (Golchin et al., 1994). The idea behind this fractioning is that the labile fractions, such as dissolved and particulate organic matter, are better available for biological decomposition, contribute more to soil structure formation, and are more sensitive to soil management than more stable fractions such as lignin (Beare et al., 1994; Tisdall and Oades, 1982).

The soil as habitat for species-rich communities has increasingly received attention for the intrinsic and functional value of soil biodiversity. High levels of biodiversity are thought to enhance stability of soil functions and services against perturbations and disturbances, and aid in the suppression of soil-borne pests and diseases (Griffiths et al., 2000; Altieri, 1999; Barrios, 2007). Soil biodiversity is also recognised as a sensitive biological indicator for effects of 
environmental change and disturbance (Wardle et al., 1995; Ritz et al., 2009; Pattison et al., 2008; Ponge et al., 2006). One of the key indicator groups is the soil microarthropods, because these are abundant, functionally diverse, and respond to a variety of ecological and environmental factors (Gardi and Parisi, 2002; Parisi et al., 2005). In addition, the area covered during the lifecycle is representative of the examined site, and their life histories permit insights into soil ecological conditions (Gardi et al., 2009).

The results presented in this paper are from a field survey on all agricultural $\mathrm{CZO}$ sites, in which soil was analysed in terms of its physical, chemical, and biological properties. Soil physical and chemical measurements included soil aggregate size fractions ( $<20,20-250,250-5000 \mu \mathrm{m})$; soil organic matter contents and distribution (based on different organic matter fractions); nutrient contents, including nitrogen $(\mathrm{N})$, phosphorus $(\mathrm{P})$, and potassium $(\mathrm{K})$; and soil $\mathrm{pH}$. Soil biological measurements included the presence and abundance of soil microbes (bacteria, fungi) and soil fauna (protozoa, nematodes and microarthropods), representing the main taxonomic groups and trophic levels in the soil food web. In addition we measured the taxonomic richness and diversity within the group of microarthropods, as well as vegetation diversity.

\section{Methods}

\subsection{Site description}

The soils analysed were sampled from the eight agricultural CZO research sites; of these, four are under sub-arctic (Iceland) and four under continental (Austria) climatic conditions. The four farms in Iceland were grassland farms, and the four in Austria were arable farms practicing crop rotations (Tables 1, 2). In each country, two farms applied "organic" practices and two farms applied "conventional" practices. The organic farms differed from the conventional farms in that only organic fertilisers were applied and no pesticides. On the conventional grassland farms in Iceland, some organic fertilisation was used in addition to the artificial inorganic fertilisers. The organic fields in Iceland were ploughed the first three consecutive years when grasslands were renewed to apply green manure, whereas conventional fields were ploughed only once. On the conventional arable farms in Austria only artificial inorganic fertilisers were applied together with pesticides. In Iceland, one pair of organic and conventional farms (in the southwest) was on Histic Andosols; the other pair (southern Iceland) was on Haplic (Brown) Andosols. In Austria, one pair of organic and conventional farms grew potatoes as the current crop; the other pair grew winter wheat. All Austrian farms were situated in the Marchfeld, southeast of Vienna, on Haplic Chernozems. Farm properties are listed in Tables 1 and 2.

\subsection{Sampling scheme}

Samples were taken in May-June $2011(0-10 \mathrm{~cm}$ in Iceland, 0-15 cm in Austria). On each farm, three plots were selected at which all measurements were carried out; the plots were approximately 30-40 m apart. At each plot, mixed soil samples (ca. $1 \mathrm{~kg}$, from 10 to 15 cores) were taken by use of a $8 \mathrm{~cm}$ diameter corer for microbial (bacteria, fungi), microfaunal (protozoa, nematodes), soil chemical and physical measurements, and a $5 \mathrm{~cm}$ diameter corer for the mesofauna (enchytraeids and microarthropods). In the grasslands on Iceland, vegetation diversity was estimated by application of four $2 \mathrm{~m}$ line transects at all farms, except for the conventional farm in southern Iceland, for which the vegetation data were supplied by the farmer. A line-intercept method was applied and four $2 \mathrm{~m}$ length tapes were laid out from the sampling point, each tape separated by $90^{\circ}$. Species were recorded each time a plant species intercepted the tape, or when a group of equally mixed plant species occurred (e.g. Kent and Coker, 1992). Vegetation richness was calculated as the total number of plant species present on the transects.

\subsection{Soil physicochemical measurements}

Particle size distribution (clay content) was determined with a combined sieve and pipette method after removal of organic matter with hydrogen peroxide and dispersion by reciprocal shaking with sodium metaphosphate solution for $12 \mathrm{~h}$ (Burt, 1992). Soil pH was measured electrochemically (microprocessor pH meter pH196 WTW, Weilheim, Germany) in $\mathrm{H}_{2} \mathrm{O}$ at a soil : solution ratio of $1: 2.5$ (Burt, 1992). Calcium $(\mathrm{Ca})$ content was measured by flame atomic absorption spectrophotometry (Perkin-Elmer 2100). Plant available $\mathrm{P}$ and $\mathrm{K}$ were determined by calcium acetate-lactate (CAL) extraction (ÖNORM L1087).

A three-step procedure was carried out to fractionate soil aggregates and organic matter. Free particulate organic matter (fPOM, 20-5000 $\mu \mathrm{m}$ ) was separated using sodium polytungstate solution (density of $1.8 \mathrm{~g} \mathrm{~cm}^{-3}$ ). To obtain particulate organic matter occluded in aggregates (oPOM, 20-5000 $\mu \mathrm{m}$ ), the heavy fraction of soil aggregates $\left(>1.8 \mathrm{~g} \mathrm{~cm}^{-3}\right)$ was treated by ultrasound $\left(8 \mathrm{~J} \mathrm{~mL}^{-1}\right)$, which disrupted the macroaggregates and protected the microaggregates (Lehtinen et al., 2014). With a subsequent density fractionation step (sodium polytungstate solution, $1.8 \mathrm{~g} \mathrm{~cm}^{-3}$ ), the oPOM floating on the suspension was obtained after centrifugation $(10 \mathrm{~min}$ at $4350 \mathrm{rpm})$. POM fractions were washed with deionised water until the electric conductivity dropped below $5 \mu \mathrm{S} \mathrm{cm}^{-1}$ (Steffens et al., 2009). The residue of the density fractionation procedure - mineral particles and organo-mineral associations - was sieved at 250 and $20 \mu \mathrm{m}$ to obtain macroaggregates $(250-5000 \mu \mathrm{m})$ and microaggregates (20-250 and $<20 \mu \mathrm{m})$. All aggregate fractions were washed with deionised water until the electronic conductivity dropped below $5 \mu \mathrm{S} \mathrm{cm}^{-1}$; subsequently they were oven- 
Table 1. Characteristics of the farms studied in Iceland (conventional farms IceHaAcon and IceHiAcon, organic farms IceHaAorg and IceHiAorg), including vegetation richness (values represent mean and standard deviation (between brackets)).

\begin{tabular}{|c|c|c|c|c|}
\hline Country & Iceland & Iceland & Iceland & Iceland \\
\hline Type & Conventional & Organic & Conventional & Organic \\
\hline Farm & IceHaAcon & IceHaAorg & IceHiAcon & IceHiAorg \\
\hline Coordinates & $\begin{array}{l}\text { N } 64^{\circ} 02^{\prime} 33.78, \\
\text { W } 20^{\circ} 12^{\prime} 18.06\end{array}$ & $\begin{array}{l}\text { N } 64^{\circ} 03^{\prime} 0.2, \\
\text { W } 20^{\circ} 10^{\prime} 44.4\end{array}$ & $\begin{array}{l}\mathrm{N} 64^{\circ} 20^{\prime} 32.82 \\
\mathrm{~W} 21^{\circ} 34^{\prime} 54.42\end{array}$ & $\begin{array}{l}\mathrm{N} 64^{\circ} 20^{\prime} 42.90, \\
\mathrm{~W} 21^{\circ} 36^{\prime} 14.22\end{array}$ \\
\hline Average temperature $\left({ }^{\circ} \mathrm{C}\right)^{*}$ & 3.6 & 3.6 & 4.3 & 4.3 \\
\hline Average rainfall $(\mathrm{mm})^{*}$ & 1120 & 1120 & 800 & 800 \\
\hline Soil type & Haplic Andosol & Haplic Andosol & Histic Andosol & Histic Andosol \\
\hline Land use type & Grassland & Grassland & Grassland & Grassland \\
\hline Last tillage & 1995 & 2003 & 1998 & 1996 \\
\hline Conversion to organic & - & 1996 & - & 1994 \\
\hline $\begin{array}{l}\text { Organic fertilisers } \\
- \text { Manure }\left(\mathrm{tha}^{-1}\right)\end{array}$ & 20 (spring) & 35 (spring) & 30 (spring) & 30 (spring) \\
\hline - Compost $\left(\mathrm{tha}^{-1}\right)$ & & 35 (fall) & & 10 (fall) \\
\hline - Cattle urine $\left(\mathrm{tha}^{-1}\right)$ & & 50 (spring) & & \\
\hline - Total N (kg N ha $\left.{ }^{-1}\right)$ & 40 & 970 & 60 & 260 \\
\hline- Total C $\left(\mathrm{tC} \mathrm{ha}^{-1}\right)$ & 0.8 & 8.6 & 1.2 & 3.2 \\
\hline $\begin{array}{l}\text { Inorganic fertilisers } \\
- \text { Total } \mathrm{N}\left(\mathrm{kg} \mathrm{ha}^{-1}\right)\end{array}$ & 80 (spring) & & 300 (spring) & \\
\hline - Total P $\left(\mathrm{kg} \mathrm{ha}^{-1}\right)$ & 20 (spring) & & & \\
\hline - Total K $\left(\mathrm{kg} \mathrm{ha}^{-1}\right)$ & 20 (spring) & & & \\
\hline Vegetation richness & 4 & $7(0)$ & $4(0)$ & $8(1.73)$ \\
\hline
\end{tabular}

* Icelandic Meteorological Office database (2012).

dried at $100^{\circ} \mathrm{C}$ and weighed. The weights of aggregates were corrected for the sand content of the same size (for aggregates 20-250, and $>250 \mu \mathrm{m}$ ) in order to exclude a sand particle from being weighed as an aggregate (Six et al., 2000; Lehtinen et al., 2014). Mean weight diameter (MWD) of the sand-corrected aggregates was calculated according to Kemper and Rosenau (1986) as the sum of the geometric means of aggregate sizes multiplied by the respective fraction.

Total carbon (TC) and nitrogen (TN) in bulk soil, aggregates, and POM fractions were quantified by dry combustion using an elemental analyser (Carlo Erba NA 1500 analyser). For the analysis, $5 \mathrm{~g}$ of sieved $(<2 \mathrm{~mm})$ soil without visible roots and litter was ground to a size $<63 \mu \mathrm{m}$ for homogenisation and $1-1.5 \mathrm{mg}$ soil was used for the analysis. Total organic carbon (TOC) was calculated as the difference of total and inorganic $\mathrm{C}$, measured as carbonate $\mathrm{C}$ by treating $0.5-2 \mathrm{~g}$ of fine-ground soil material with $10 \% \mathrm{HCl}$ acid and quantifying the evolved $\mathrm{CO}_{2}$. Hot-water-extractable carbon (HWC) was measured as the $\mathrm{C}$ present in solution after $16 \mathrm{~h}$ at $80^{\circ} \mathrm{C}$, while water-soluble carbon (WSC) was measured after $30 \mathrm{~min}$ at $20^{\circ} \mathrm{C}$ (Ghani et al., 2003). Labile carbon was defined as HWC, while recalcitrant carbon was determined as the difference between TOC and labile carbon. Potentially mineralisable nitrogen (PMN) was measured as the increase in $\mathrm{NH}_{4}$ during 1 week of anoxic incubation in slurry at $40^{\circ} \mathrm{C}$ (Canali and Benedetti, 2006). Potential carbon and nitrogen mineralisation were measured by incubation of $200 \mathrm{~g}$ of homogenised and sieved soil for 6 weeks at $20^{\circ} \mathrm{C}$ (Bloem et al., 1994). Results of the first week (disturbance) were not used. $\mathrm{N}$ mineralisation was calculated from the increase in mineral $\mathrm{N}$ (nitrate and ammonium) between week 1 and week 6 . Total concentrations of $\mathrm{O}_{2}$ and $\mathrm{CO}_{2}$ were measured weekly using a gas chromatograph (Carlo Erba GC 6000) equipped with a hotwire detector (HWD 430) and helium as carrier gas, and weekly rates were calculated from that. Only bottles in which $\mathrm{O}_{2}$ concentration dropped below $15 \%$ within the 6-week period were flushed and reset to environmental concentrations to prevent $\mathrm{O}_{2}$ limitation. For the statistical analyses, we took the average of weekly rates over the 5-week period after the first week.

\subsection{Soil food web measurements}

The soils were analysed for the presence and abundances of the major taxonomic groups of soil organisms: bacteria, fungi, protozoa, nematodes, enchytraeids, and microarthropods. Within these taxonomic groups we defined "trophic groups" based on diet and life-history traits, following the method of Moore et al. (1988). Abundances were transformed into estimates of biomass based on body-size information, and expressed in units of kilograms of carbon per hectare for the $0-10 \mathrm{~cm}$ top soil layer. 


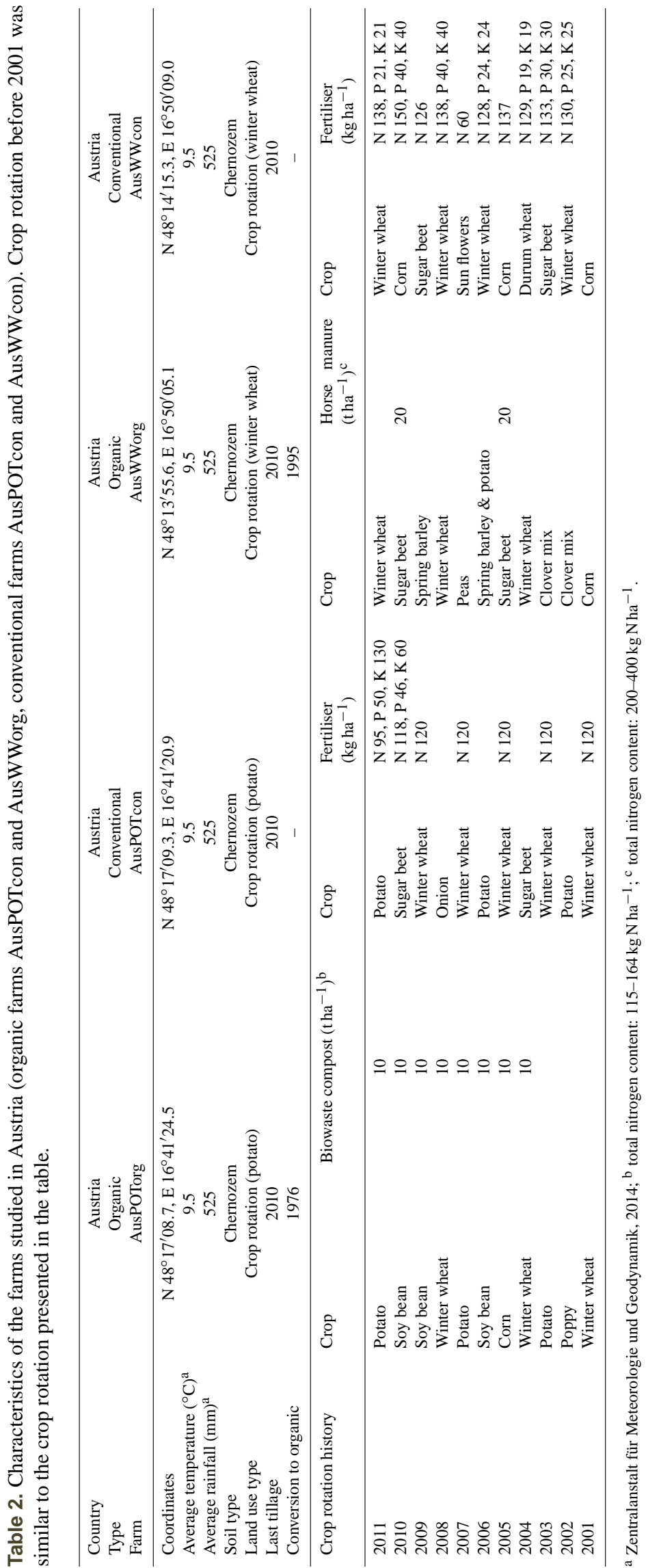


Bacterial biomass, fungal biomass, leucine incorporation, and protozoa were measured after a pre-incubation period of 2 weeks at $20^{\circ} \mathrm{C}$. Bacterial numbers and cell volumes, and fungal hyphal lengths were measured in microscopic slides (Bloem and Vos, 2004). Bacterial cell numbers and volumes were determined using confocal laser scanning microscopy combined with an image analysis system. The data were transformed into bacterial biomass, taking a spe-

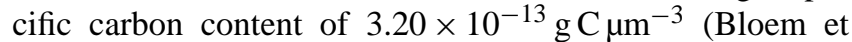
al., 1995). For the transformation of fungal hyphal lengths to fungal biomass we described fungal volume as a cylinder with spherical ends $\left(V=(\pi / 4) W^{2}(L-W / 3)\right.$, where $V=$ volume in $\mu \mathrm{m}^{3}, L=$ length in $\mu \mathrm{m}$, and $W=$ diameter in $\mu \mathrm{m}$ ), with a mean hyphal diameter of $2.5 \mu \mathrm{m}$ and a specific

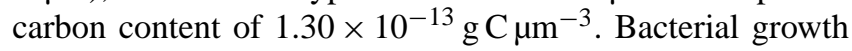
activity was estimated by measuring incorporation rates of $\left[{ }^{14} \mathrm{C}\right]$ leucine (Bloem and Bolhuis, 2006).

Two trophic groups of protozoa (flagellates and amoebae) were measured using the most-probable-number method (Bloem et al., 1994). Numbers were converted to biomass assuming a spherical shape with diameters of 4.6 and $9.1 \mu \mathrm{m}$ for flagellates and amoebae, respectively, and a volume-to-C conversion factor of $1 \times 10^{-13} \mathrm{C}^{-3}$ (Bloem et al., 1994).

Soil nematodes were counted in $9 \mathrm{~mL}$ of soil solution extracted by Oostenbrink elutriators from $100 \mathrm{~g}$ of soil. Numbers per trophic group (bacterivore, fungivore, herbivore, omnivore, predaceous) were derived from species composition in the samples (Bongers, 1988). Nematode biomasses were calculated using fresh weight data from Didden et al. (1994) and taking a moisture content of $75 \%$ and a carbon content of $40 \%$ (Didden et al., 1994).

Enchytraeid numbers were obtained through a (wet) extraction using Baermann funnels with increasing light and heat each $30 \mathrm{~min}$ after the start of the extraction over a total extraction time of $3 \mathrm{~h}$. Enchytraeid numbers were converted into biomass $\mathrm{C}$ by measuring the average fresh weight and taking a moisture content of $85 \%$ and a carbon content of $50 \%$ of the dry weight (Didden et al., 1994).

Microarthropods were extracted from four soil cores of $196 \mathrm{~mL}$ per replicate, during a 1-week period with Tullgren funnels, and processed using the gel-based sub-sample methodology (Jagers op Akkerhuis et al., 2008). Total numbers were recorded, while species composition was assessed in sub-samples of 100 individuals following Jagers op Akkerhuis et al. (2008), and references therein. Microarthropod biomass $\mathrm{C}$ was calculated based on individual weights, moisture contents, and C contents from Didden et al. (1994).

Microarthropod diversity was quantified in three ways: by absolute number of taxa present, by the Shannon diversity index $(H)$, and by the Pielou evenness index. For the Shannon diversity index $(H)$ we used the following formula:
$H=-\sum_{i=1}^{S}\left(p_{i} \times \ln p_{i}\right)$,

in which $p_{i}$ is the proportion of the total biomass $(S)$, i.e. the relative biomass, of species $i$. For the Pielou evenness index $(J)$ we used the formula

$J=\frac{H}{\ln (N)}$,

in which $H$ represents the Shannon diversity index and $N$ the total number of taxa present.

\subsection{Statistics}

The data were from eight farms that differed in various ways: climate, soil type, soil management, and crop. There were no real replicates, as the triplicate measurements for all variables were from plots on the same farm. Hence, we performed a nested two-way ANOVA with two factors: country (IcelandAustria) and farm management (organic-conventional), and farm as a random nested factor. By taking country as a factor, we separated the grassland (Iceland) from the cropland (Austria) farms. By including farm as a random nested factor, we accounted for the variation among farms. We tested the differences between soil types separately using a one-way ANOVA with soil as a factor. All data were log-transformed to obtain homogeneity of variances. Statistical analyses were carried out using SPSS (20.0.0) and R (2.15.2).

\section{Results}

\subsection{Soil physicochemical measurements}

Many physicochemical soil characteristics varied strongly over farms, as a consequence of different soil types, soil management, and climatic conditions (countries) (Table 3). The most pronounced differences were found between the soils from the two different countries. Clay content was lowest in the Haplic Andosols in Iceland $(p=0.001)$. Soils in Austria were alkaline $(\mathrm{pH} 8)$ as a result of the much higher calcium content of the Chernozems, whereas the Andosols in Iceland had a lower $\mathrm{pH}(\mathrm{pH} 5-6)$. Plant available nutrients $(\mathrm{P}, \mathrm{K})$ were much higher on the farms in Austria than in Iceland, due to the strong nutrient retention in Andosols $(p=0.001$ and $p=0.026$, Table 3).

For the MWD of soil aggregates, we found a difference between farm management: on the organic farms in Iceland the MWD was more than twice as high as on the conventional farms, although the difference was not statistically significant $(p=0.173)$. The opposite was found in Austria, although here the differences were relatively small (Table 3). Mean weight diameter was positively correlated to fungal (Pearson test, $r=0.739, p=0.006$ ) and bacterial biomass (Pearson test, $r=0.664, p=0.019$ ), whereas 


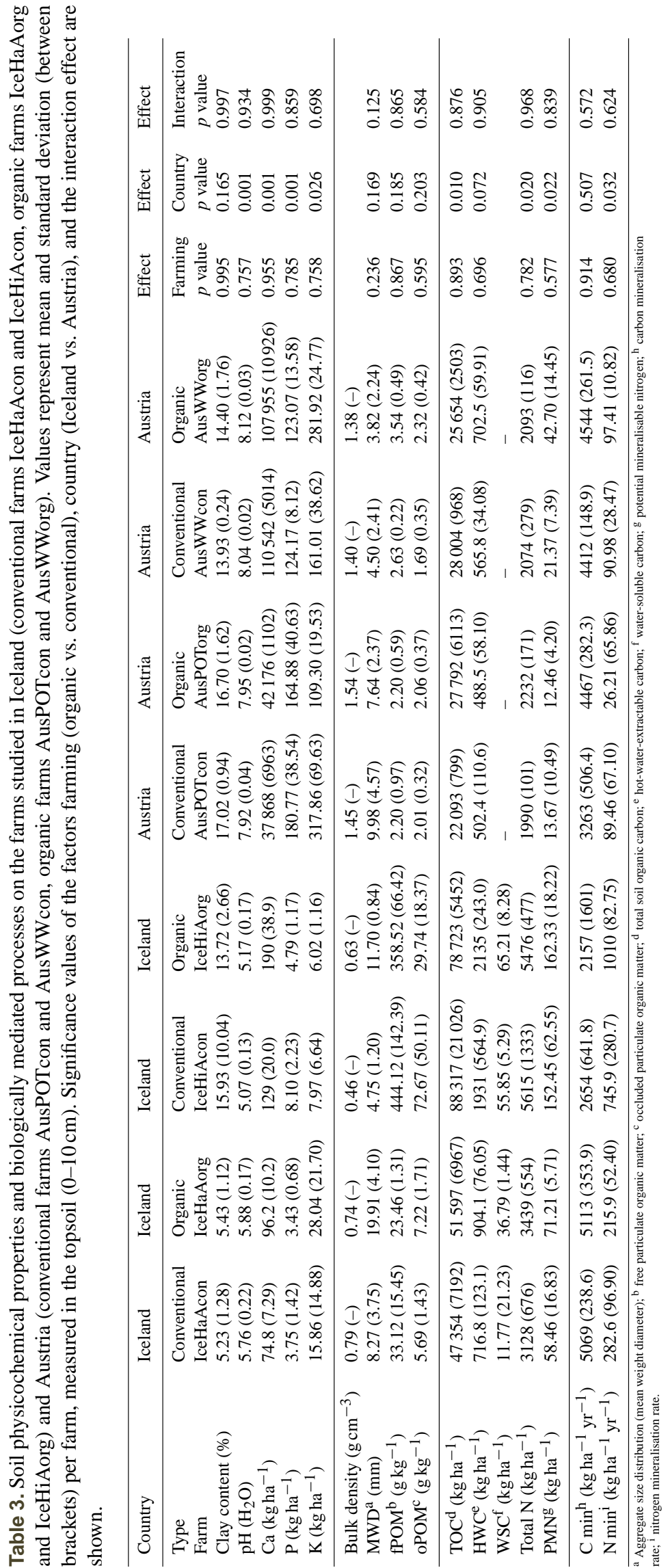




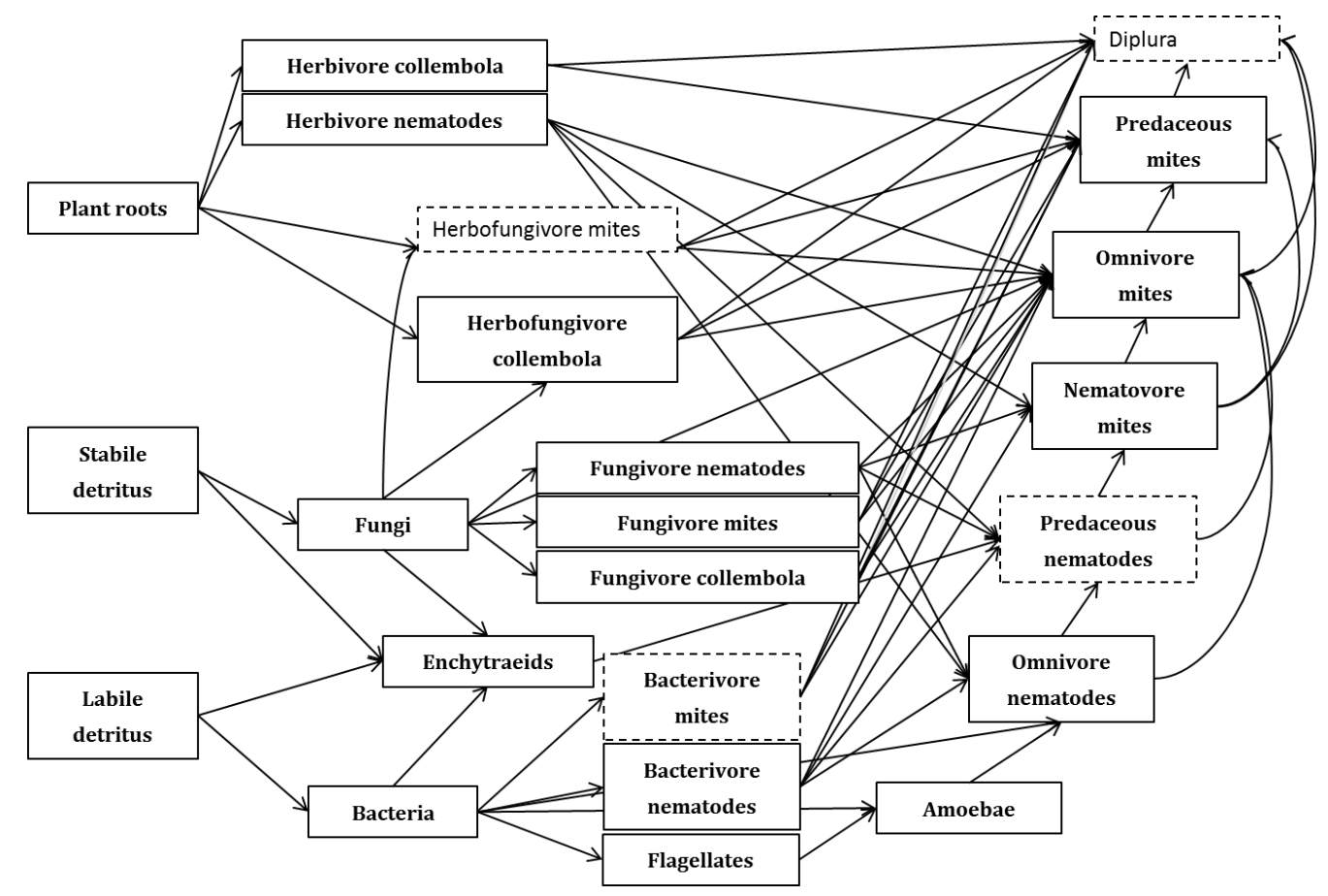

Figure 1. Soil food web diagram representative for all eight farms. Boxes represent the presence of trophic groups in the soil food web, and arrows represent feeding interactions based on diet information. Solid groups were present at all farms, and dashed groups were only present at some farms.

no significant correlations were found with organic matter parameters. The content of free particulate organic matter (fPOM) and occluded particulate organic matter (oPOM) varied strongly between the different countries and between soil types within countries. The fPOM content in the Icelandic Histic Andosols (358-444 $\mathrm{g} \mathrm{kg}^{-1}$ ) was higher than in the Icelandic Haplic Andosols $\left(23-33 \mathrm{~g} \mathrm{~kg}^{-1}\right)$ and all Austrian soils $\left(2-3 \mathrm{~g} \mathrm{~kg}^{-1}, p<0.001\right)$. The oPOM content showed a similar pattern. The high contents of particulate organic matter in Iceland, especially in the Histic Andosols, reflect the very high content of organic carbon (contents of TOC, HWC, and WSC) and nitrogen (both total N and PMN $)$ in these soils: TOC $(p=0.010)$, HWC $(p=0.072)$, total $\mathrm{N}(p=0.020)$, and PMN $(p=0.022)$ were all higher in Iceland compared to Austria. The farms on Histic Andosols in Iceland had a lower C mineralisation rate (2157$2654 \mathrm{~kg} \mathrm{ha}^{-1} \mathrm{yr}^{-1}$ ), but a much higher potential $\mathrm{N}$ mineralisation rate (746-1010 $\left.\mathrm{kg} \mathrm{ha}^{-1} \mathrm{yr}^{-1}\right)$, than the farms on Haplic Andosols in Iceland; these differences were even more pronounced compared to the farms in Austria $(p=0.032)$.

The way organic carbon $(\mathrm{OC})$ and nitrogen $(\mathrm{N})$ were distributed over aggregate sizes and organic matter fractions, was also different between farms. On the organic farm on Haplic Andosol in Iceland, macroaggregates $>250 \mu \mathrm{m}$ contributed the greatest quantities of OC and $\mathrm{N}$ to bulk soil $(65 \%$ OC, $65 \%$ for N). On both farms on Histic Andosols in Iceland the PPOM fraction contributed the largest quantities of
OC and $\mathrm{N}$ to bulk soil (61 and $69 \%$ for OC and 56 and $62 \%$ for $\mathrm{N}$, respectively). On the winter wheat farms in Austria, microaggregates of 20-250 $\mu \mathrm{m}$ contributed the greatest quantities of OC and $\mathrm{N}$ to bulk soil (46 and $50 \%$ for OC and 45 and $45 \%$ for $\mathrm{N}$, respectively), while on the potato farms in Austria the microaggregates $<20 \mu \mathrm{m}$ contributed the greatest quantities of OC and $\mathrm{N}$ to bulk soil (51 and $46 \%$ for OC and 51 and $47 \%$ for $\mathrm{N}$, respectively).

\subsection{Soil food web measurements}

Based on presence-absence data of the soil organisms, we constructed soil food web diagrams for all farms (Fig. 1). These diagrams were very similar; despite differences in climatic conditions, crop type, soil type, and soil management, most of the trophic groups were present on all farms. Some of the trophic groups were only present at some farms, including predaceous nematodes, bacterivore mites, herbofungivore mites, and Diplura (Fig. 1, Table 4).

Trophic groups showed differences in abundances (Table 3) and species composition (see microarthropod diversity). Bacterial biomass was consistently higher on organic farms in both countries, although the differences were not statistically significant. Bacterial activity, measured as the incorporation rate of $\left[{ }^{14} \mathrm{C}\right]$ leucine, did not differ significantly between farms. Fungal biomass did not show a consistent pattern over all farms, although fungal biomass tended to be lower on the farms on Histic Andosols. Protozoa 


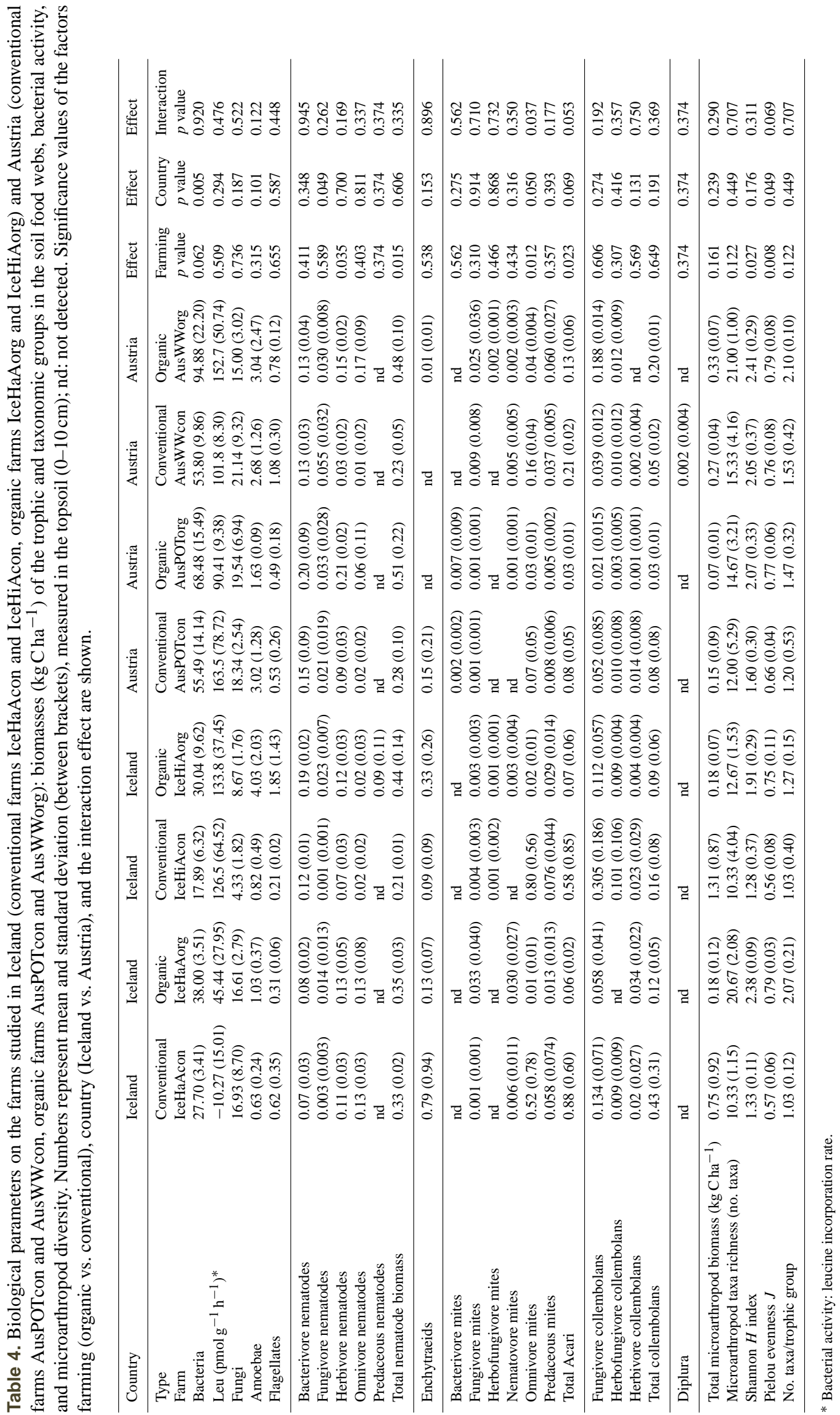


(amoebae, flagellates) and enchytraeids showed no clear pattern in biomass (Table 4).

Nematode biomass was consistently higher on organic farms than in conventional farms, regarding all trophic groups, although differences were only statistically significant for herbivorous nematodes $(p=0.035)$ and total nematode biomass ( $p=0.015$, Fig. $2 \mathrm{~b}$ ).

Microarthropod abundance varied strongly from just over $12000 \mathrm{~m}^{-2}$ to over $200000 \mathrm{~m}^{-2}$. We did not find systematic differences between country or management type. Total microarthropod biomass was much higher on the conventional farms in Iceland compared to all other farms (Fig. 2c). Total Acari biomass was significantly higher on conventional farms compared to organic farms ( $p=0.023$, Table 4$)$. The higher biomass of omnivorous mites $(p=0.012)$ and, to a lesser extent, also the consistently higher Acari biomass ( $p=0.023$ ) on conventional farms was fully accounted for by the high biomass of the astigmatid mite Tyrophagus similis. T. similis accounted for 98.1 and $99.7 \%$ of the total omnivorous mite biomass, and 59.8 and $69.7 \%$ of the total microarthropod biomass in the conventional grasslands in Iceland, while this species was (nearly) absent at all other farms (Appendix A). In Iceland, collembolan biomass was higher on conventional farms compared to organic farms (Table 4).

\subsection{Microarthropod species identity and diversity}

In total, 82 taxa of microarthropods were found in our study sites, with an overall larger diversity in Austria than Iceland. All farms showed striking differences in the microarthropod species composition: only 3 out of the 82 taxa were present on all farms (the mesostigmatid Arctoseius cetratus and the prostigmatids Eupodes sp. and Pygmephorus sp.). In Iceland, 27 taxa were found that did not occur in Austria, and 37 taxa were found only in Austria, while only 18 taxa were found in both countries. The number of taxa only occurring on organic farms amounted to a total of 33, either in Iceland (14 taxa) or in Austria (18 taxa), while 1 taxon (Tyrophagus sp.) was found on organic farms in both Iceland and Austria. Moreover, 12 taxa were found only on conventional farms, of which 5 were in Iceland and 7 in Austria. The organic wheat farm in Austria had a remarkably high microarthropod taxonomic richness, with 34 taxa present, of which 12 were unique to that farm. The conventional grasslands in Iceland in particular had low taxonomic richness of only 18 taxa (HiAcon) and 17 taxa (HaAcon).

Organic farms had a significantly higher microarthropod diversity measured according to all diversity measures; for the Shannon index ( $p=0.027$, Fig. 3a) and the Pielou index for evenness ( $p=0.008$, Fig. 3b), differences were statistically significant; for taxonomic richness it was not statistically significant ( $p=0.122$, Fig. 3c).

\section{Discussion}

In this study we investigated soil quality parameters (physical, chemical, and biological) on the organically and conventionally managed farms that are part of the European CZO network.

\subsection{Soil aggregate formation, soil organic matter, and soil nutrient cycling}

Regarding soil structure formation and soil organic matter, the different farming practices, organic versus conventional, did not reveal systematic differences in many physical and chemical soil properties. The soil aggregate size distributions were consistently higher on organic than on conventional farms in Iceland, but no differences were found in Austria. Other management practices such as tillage (Beare et al., 1994) or crop rotation history may have obscured effects of organic amendments. For example, the arable farms in Austria applied a crop rotation with a yearly tillage. As soil aggregates are sensitive to soil tillage (Beare et al., 1994, 1997; Six et al., 2000), it could be expected that the differences between organic and conventional arable farms are comparably small. In contrast, the Icelandic grasslands had not been tilled for 8-16 years (Table 1). Also, the addition of higher quantities of organic amendments was expected to have a positive effect through enhanced soil biological activity, in terms of aggregate-forming substances. However, the observed higher mean weight diameters on the organic farms on Iceland could not be linked to higher organic matter contents, e.g. in terms of total carbon, or a difference in organic matter composition. However, mean weight diameter of aggregates was significantly correlated with fungal and bacterial biomass. Both bacteria and fungi produce soil-binding compounds like polysaccharides, which are important for production of relatively small aggregates (de Gryze et al., 2005; Wright et al., 2007). Soil fungi are assumed to be especially more important for the formation of larger soil aggregates through entanglement by hyphae (Tisdall and Oades, 1982).

Regarding the soil carbon and nitrogen, we also did not detect systematic differences between organic and conventional farming. $\mathrm{C}$ and $\mathrm{N}$ mineralisation rates as well as the measured $\mathrm{C}$ and N pools (TOC, HWC, total N, PMN; Table 3) were quite similar on organic and conventional farms. Furthermore, bacterial activity was similar on organic and conventional farms. The present results partly confirm the results reported from earlier studies (van Diepeningen et al., 2006; Bloem et al., 2006).

In summary, $\mathrm{C}$ and $\mathrm{N}$ contents and dynamics between organic and conventional farms have been studied in three different ways: factorial field experiments on a single farm, pairwise comparisons of farms (as in our study), and comparisons across a larger number of farms $(n=10-20)$. In a factorial field experiment on an arable farm, the Lovinkhoeve in the Netherlands, Bloem et al. (1994) found a higher C and 

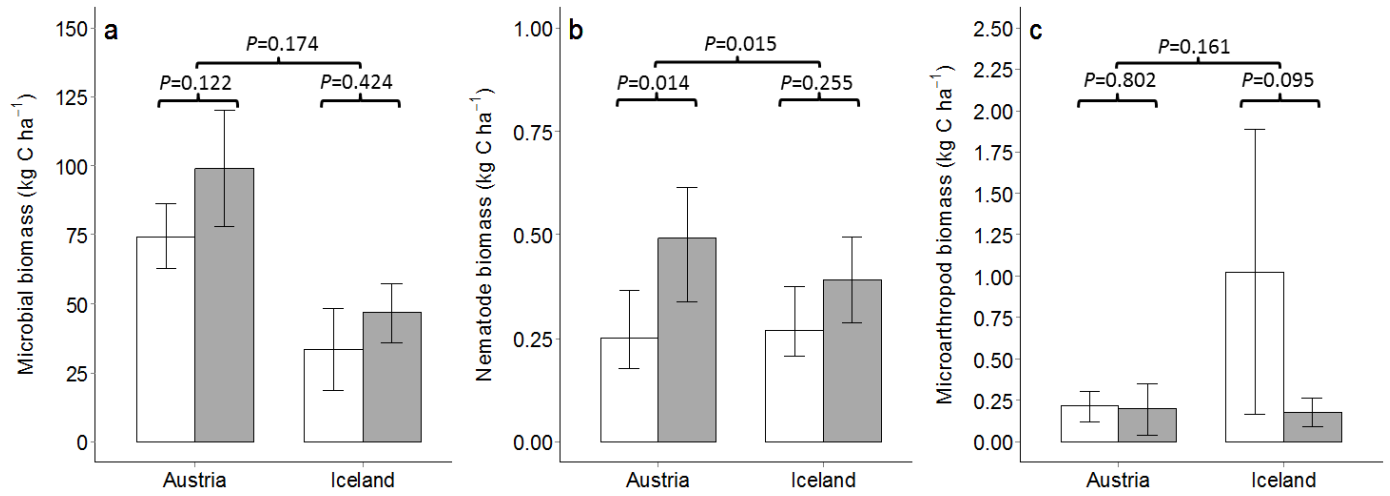

Figure 2. Biomass in $\mathrm{kg} \mathrm{Cha}^{-1}$ of microbes (bacteria+fungi) (a), nematodes (b), and microarthropods (c) on organic and conventional farms in Austria and Iceland. Bars are means \pm standard deviation $(n=6)$, measured in the topsoil $(0-10 \mathrm{~cm}) . P$ values are the results of a nested univariate analysis of variance (ANOVA), with type (conventional (white bars) or organic (grey bars)) and country (Austria or Iceland) as factors.
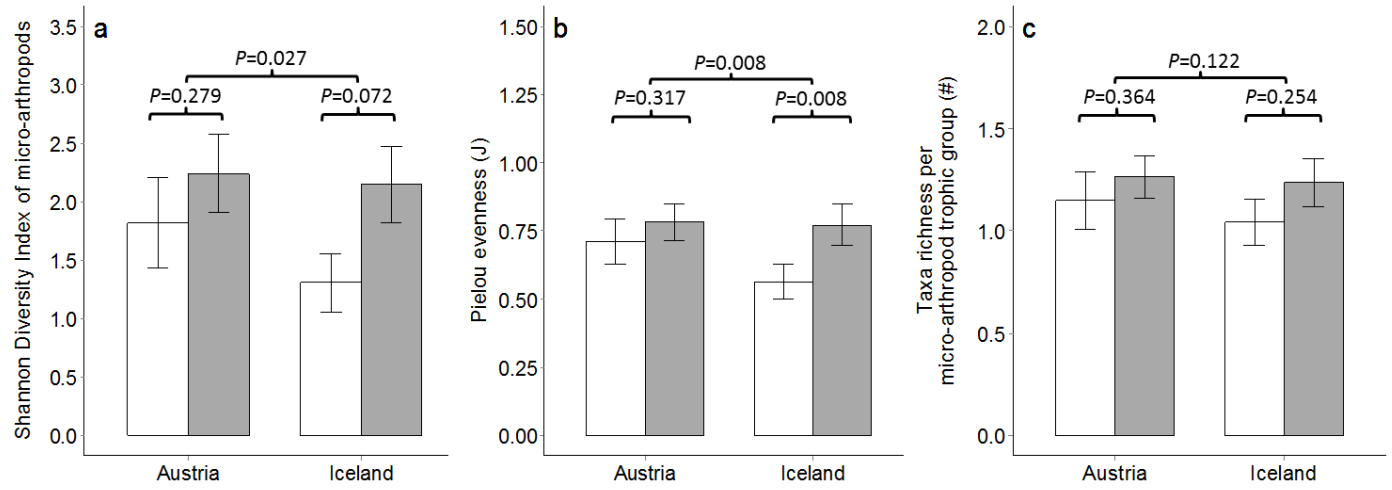

Figure 3. Shannon diversity index on microarthropod taxa (a), Pielou evenness on microarthropod taxa (b), and absolute microarthropod taxa richness (c) on organic and conventional farms in Austria and Iceland. Bars are means \pm standard deviation $(n=6)$, measured in the topsoil $(0-10 \mathrm{~cm}) . P$ values are the results of a nested univariate analysis of variance (ANOVA), with type (conventional (white bars) or organic (grey bars)) and country (Austria or Iceland) as factors.

$\mathrm{N}$ mineralisation in an integrated field compared to a conventional field, probably as a result of organic amendments. Similarly, on a grassland farm in the Netherlands, a higher $\mathrm{N}$ mineralisation and potentially mineralisable $\mathrm{N}$ has been measured when organic fertiliser was applied, while no difference has been found in C mineralisation (van Eekeren et al., 2009). Also, Poudel et al. (2002) found a higher potential $\mathrm{N}$ mineralisation in organically managed crop rotation fields than in conventional fields in California, but there the organic fields also grew legumes between growing seasons, enhancing $\mathrm{N}$ availability. In Switzerland, Birkhofer et al. (2008) observed a lower $\mathrm{N}$ mineralisation when only mineral fertiliser was used, while $\mathrm{C}$ mineralisation did not show differences between the fields. Also, in this study, no differences were found between organic fields and fields that received both artificial fertilisers and organic manure, similar to the Icelandic grasslands in the present study. Thus, in factorial experiments on a single farm, the effects of organic management on soil
$\mathrm{N}$ dynamics are quite clear, while the effects on $\mathrm{C}$ dynamics are not consistent.

In an example of a pairwise comparison between organic and conventional arable farms in the Netherlands, van Diepeningen et al. (2006) observed lower nitrate levels on organic farms, with no differences in total organic $\mathrm{C}$, organic $\mathrm{N}$, or total $\mathrm{N}$. Conventional farms in that study also applied organic manure in addition to artificial fertilisers, which is comparable to the grasslands in Iceland, where we also did not find differences in total organic $\mathrm{C}$ and total N. In an example of a comparison across larger number of farms in the Netherlands ( $n=10-20)$, Bloem et al. (2006) showed higher $\mathrm{C}$ and $\mathrm{N}$ mineralisation rates in organic grasslands compared to conventional grasslands, but not in the comparison between organic and conventional arable farms. Thus, our study confirms the notion that more factors are variable and differences between organic and conventional farming are less prominent when $\mathrm{C}$ and $\mathrm{N}$ dynamics are studied on a larger scale with more farms involved. 


\subsection{Soil food web structure}

The trophic structure of the soil food webs showed a high similarity; nearly all trophic groups were present on all farms. This indicates that the trophic structure of the soil food webs was neither very sensitive to management nor to climate, soil type, and farm type. Biomass of the different organisms, however, differed between farms.

Microbial biomass, as the sum of bacteria and fungi, was consistently higher on organic farms, although not statistically significant. The higher microbial biomass, especially bacterial biomass, is in line with previous studies that have compared organic and conventional farms (Bloem et al., 2006; Hole et al., 2005; Haubert et al., 2009; Mäder et al., 2002; Birkhofer et al., 2008; van Diepeningen et al., 2006; Gunapala and Scow, 1998). Other studies also have reported a higher microbial activity (Bloem et al., 2006; Hole et al., 2005), which we did not find in our study. We did not find differences in fungal biomass, in contrast with some previous results (Yeates et al., 1997; de Vries et al., 2006), but in line with others (Shannon et al., 2002). These results might be due to the fact that added organic amendments in organic farming are generally easily degradable and therefore enhance mainly bacterial biomass and activity (Hole et al., 2005).

We observed a significantly higher total nematode biomass on organic farms. Although a higher biomass was observed for all trophic groups of nematodes, the difference was mostly accounted for by herbivorous nematodes. This is in agreement with the higher nematode abundance that was found after addition of organic manure to wheat fields in Switzerland, where herbivorous nematodes were also the dominant group (Birkhofer et al., 2008). It is also in agreement with the higher nematode abundance (although dominated by fungivores) found in organic grasslands in Wales (Yeates et al., 1997). Hence, our results support the notion that nematodes are sensitive to farming type and that they profit from the addition of organic amendments.

Microarthropod biomass measurements did not reveal systematic differences between farm types, although total microarthropod biomass was highest on the conventional farms within Iceland. We also did not find a difference between the grassland farms in Iceland and the arable farms in Austria. This is a bit unexpected because it is frequently observed that microarthropod biomass is higher in grasslands compared to arable farms, because ploughing decreases microarthropod biomass, which is more intense for root/tuber crops such as potato (Vreeken-Buijs et al., 1998). In our study, the organic grasslands in Iceland were, however, ploughed in the three consecutive years when the field was renewed, which, together with the colder climatic conditions, may explain why biomass of microarthropods was not higher in the grasslands than in the arable fields (Sjursen et al., 2005).

We found a statistically higher biomass of mites (Acari) on the conventional farms compared to the organic farms.
We lack an explanation for this somewhat unexpected result. For example, it is contrary to the results from an earlier study, showing higher abundances of Acari in organic grasslands compared to conventional grasslands in Wales (Yeates et al., 1997). The similar collembolan biomass on organic and conventional farms is in line with the results of Birkhofer et al. (2008) in Switzerland, but in contrast with the results of Bardgett et al. (1993), who reported higher collembolan biomass in organic fields. The two species of collembolans that are by far the most abundant in the study of Bardgett et al. (1993) were much less abundant (Onychiurus procampatus) or even absent (Folsomia quadrioculata) in our data, which may explain the difference between the studies.

\subsection{Microarthropod diversity}

The most systematic difference we found in the comparison between organic and conventional farming was the higher microarthropod diversity on the organically managed farms. This difference was found across countries, farm types (grassland versus arable), and crop and soil type. This finding is in agreement with Doles et al. (2001) and Macfadyen et al. (2009).

Factors known to enhance soil microarthropod diversity include plant litter diversity leading to a higher microhabitat and resource diversity (Hansen and Coleman, 1998) and plant species identity (Wardle et al., 2005). In Iceland, organic grasslands had a higher plant diversity than conventional grasslands, which supports the hypothesis that plant diversity enhances belowground microarthropod diversity. On the arable farms in Austria, where plant diversity does not play a role, the application of artificial fertilisers may have reduced the microarthropod diversity (Siepel and Van de Bund, 1988).

Soil microarthropod diversity is described as a sensitive biological indicator for effects of environmental change and disturbance on soil quality (Gardi and Parisi, 2002; Parisi et al., 2005; Gardi et al., 2009). Our results confirm that the taxonomic diversity of the soil microarthropods was sensitive to differences in farm type and management system.

If we look at these findings in terms of the role of biodiversity in ecosystem functioning, we see that the higher microarthropod diversity on organic farms did not result in differences in the food web structure, nor did it yield higher ecosystem services, such as soil fertility or $\mathrm{C}$ sequestration. This is in agreement with Setälä et al. (2005), who argue that the functional importance of individual groups is rather high at coarse (trophic group) level but low at species level, and that effects of species diversity on ecosystem functioning are most likely found in studies with a very low species richness and therefore a low functional redundancy. Nevertheless, in our study microarthropod diversity was found to be a sensitive and consistent indicator for land management. At present, determining microarthropod diversity is a relatively intensive activity, but when the current progresses in method- 
ology lead to faster and cheaper analyses, such as barcoding extracted microarthropods, soil microarthropod diversity will become more cost-effective and an even more valuable indicator for soil quality.

\subsection{Conclusions}

In this study we investigated soil biological, chemical, and physical parameters for soil quality on organically and conventionally managed farms. The chosen farms were part of the European Critical Zone Observatory network. Factors that vary across farms - such as climate, soil type, and farm type, and the limited number of replicates taken - have made it difficult to find clear patterns or draw general conclusions. On the other hand, we did observe that the organic farms showed higher biological parameters, in particular the diversity in soil microarthropod diversity, despite these limitations. Physical and chemical parameters showed no clear differences between the organic and conventional farms. Our results therefore do support the use of microarthropod diversity as a soil quality indicator, although physical and chemical soil properties are indispensable for a complete assessment and understanding of soil quality. 


\section{Appendix A}

Table A1. Biomass $\left(\mathrm{kg} \mathrm{Cha}^{-1}\right)$ of the microarthropod taxa in the soil food web on the farms studied in Iceland (conventional farms IceHaAcon and IceHiAcon, organic farms IceHaAorg and IceHiAorg) and Austria (conventional farms AusPOTcon and AusWWcon, organic farms AusPOTcon and AusWWorg). Trophic groups: omnivorous mites (Ommi), bacterivorous mites (Bami), fungivorous mites (Fumi), nematovorous mites (Nemi), predatory mites (Prmi), herbofungivorous mites (HFmi), herbofungivorous collembolans (HFco), fungivorous collembolans (Fuco), and diplurans (Dipl). Numbers represent mean and standard deviation (between brackets), measured in the topsoil $(0-10 \mathrm{~cm})$.

\begin{tabular}{|c|c|c|c|c|c|c|c|c|c|}
\hline Country & & Iceland & Iceland & Iceland & Iceland & Austria & Austria & Austria & Austria \\
\hline $\begin{array}{l}\text { Type } \\
\text { Farm }\end{array}$ & & $\begin{array}{l}\text { Conventional } \\
\text { IceHaAcon }\end{array}$ & $\begin{array}{l}\text { Organic } \\
\text { IceHaAorg }\end{array}$ & $\begin{array}{l}\text { Conventional } \\
\text { IceHiAcon }\end{array}$ & $\begin{array}{l}\text { Organic } \\
\text { IceHiAorg }\end{array}$ & $\begin{array}{l}\text { Conventional } \\
\text { AusPOTcon }\end{array}$ & $\begin{array}{l}\text { Organic } \\
\text { AusPOTorg }\end{array}$ & $\begin{array}{l}\text { Conventional } \\
\text { AusWWcon }\end{array}$ & $\begin{array}{l}\text { Organic } \\
\text { AusWWorg }\end{array}$ \\
\hline $\begin{array}{l}\text { Acari } \\
\text { Astigmata } \\
\text { Acaridae }\end{array}$ & Ommi & & $0.0063(0.011)$ & & & & & & \\
\hline Astigmata & Ommi & & & & & & $\begin{array}{l}0.0010 \\
(0.0018)\end{array}$ & & \\
\hline Histiostoma & Bami & & & & & $\begin{array}{l}0.0002 \\
(0.0002)\end{array}$ & $\begin{array}{l}0.0007 \\
(0.0009)\end{array}$ & & \\
\hline Rhizoglyphus & Fumi & & $\begin{array}{l}0.0314 \\
(0.0395)\end{array}$ & & & & & & \\
\hline Schwiebea & Fumi & & & & & & & & $\begin{array}{l}0.0205 \\
(0.0347)\end{array}$ \\
\hline Tyrophagus & Ommi & & $\begin{array}{l}0.0003 \\
(0.0005)\end{array}$ & & & & & & $\begin{array}{l}0.0020 \\
(0.0017)\end{array}$ \\
\hline $\begin{array}{l}\text { Tyrophagus } \\
\text { similis }\end{array}$ & Ommi & $\begin{array}{l}0.5194 \\
(0.7805)\end{array}$ & & $\begin{array}{l}0.7801 \\
(0.5551)\end{array}$ & $\begin{array}{l}0.0002 \\
(0.0004)\end{array}$ & & $\begin{array}{l}0.0003 \\
(0.0005)\end{array}$ & & \\
\hline $\begin{array}{l}\text { Mesostigmata } \\
\text { Alliphis sicu- } \\
\text { lus }\end{array}$ & Nemi & $\begin{array}{l}0.0020 \\
(0.0034)\end{array}$ & $\begin{array}{l}0.0094 \\
(0.0086)\end{array}$ & & $\begin{array}{l}0.0003 \\
(0.0005)\end{array}$ & & $\begin{array}{l}0.0001 \\
(0.0002)\end{array}$ & $\begin{array}{l}0.0012 \\
(0.0011)\end{array}$ & $\begin{array}{l}0.0006 \\
(0.0010)\end{array}$ \\
\hline Arctoseius & Prmi & & & & $\begin{array}{l}0.0007 \\
(0.0012)\end{array}$ & & & & \\
\hline $\begin{array}{l}\text { Arctoseius ce- } \\
\text { tratus }\end{array}$ & Prmi & $\begin{array}{l}0.0320 \\
(0.0553)\end{array}$ & $\begin{array}{l}0.0031 \\
(0.0054)\end{array}$ & $\begin{array}{l}0.0207 \\
(0.0256)\end{array}$ & $\begin{array}{l}0.0186 \\
(0.0130)\end{array}$ & $\begin{array}{l}0.0032 \\
(0.0056)\end{array}$ & $\begin{array}{l}0.0015 \\
(0.0015)\end{array}$ & $\begin{array}{l}0.0067 \\
(0.0117)\end{array}$ & $\begin{array}{l}0.0169 \\
(0.0118)\end{array}$ \\
\hline $\begin{array}{l}\text { Arrhopalites } \\
\text { caecus }\end{array}$ & Prmi & & & & $\begin{array}{l}0.0011 \\
(0.0020)\end{array}$ & & & & \\
\hline Dendrolaelaps & Prmi & & & & & & $\begin{array}{l}0.0011 \\
(0.0010)\end{array}$ & & \\
\hline $\begin{array}{l}\text { Dendrolaelaps } \\
\text { rectus }\end{array}$ & Prmi & & & & & & & & $\begin{array}{l}0.0101 \\
(0.0174)\end{array}$ \\
\hline $\begin{array}{l}\text { Dendrolaelaps } \\
\text { samsinaki }\end{array}$ & Prmi & & & & & & & & $\begin{array}{l}0.0034 \\
(0.0058)\end{array}$ \\
\hline $\begin{array}{l}\text { Dendrolaelaps } \\
\text { zwoelferi }\end{array}$ & Prmi & & & & & & & & $\begin{array}{l}0.0026 \\
(0.0045)\end{array}$ \\
\hline $\begin{array}{l}\text { Dinychus per- } \\
\text { foratus }\end{array}$ & Ommi & & $\begin{array}{l}0.0010 \\
(0.0018)\end{array}$ & & & & & & \\
\hline $\begin{array}{l}\text { Evimirus } \\
\text { uropodinus }\end{array}$ & Nemi & & & & & & $\begin{array}{l}0.0001 \\
(0.0002)\end{array}$ & & \\
\hline Hypoaspis & Prmi & & & & & & $\begin{array}{l}0.0006 \\
(0.001)\end{array}$ & & $\begin{array}{l}0.0043 \\
(0.0075)\end{array}$ \\
\hline $\begin{array}{l}\text { Hypoaspis ac- } \\
\text { uleifer }\end{array}$ & Prmi & & & & & & & $\begin{array}{l}0.0025 \\
(0.0044)\end{array}$ & \\
\hline Lysigamasus & Prmi & $\begin{array}{l}0.0063 \\
(0.0059)\end{array}$ & $\begin{array}{l}0.0043 \\
(0.0048)\end{array}$ & $\begin{array}{l}0.0043 \\
(0.074)\end{array}$ & & & $\begin{array}{l}0.0011 \\
(0.0018)\end{array}$ & & \\
\hline $\begin{array}{l}\text { Lysigamasus } \\
\text { runciger }\end{array}$ & Prmi & $\begin{array}{l}0.0178 \\
(0.0263)\end{array}$ & $\begin{array}{l}0.0047 \\
(0.0042)\end{array}$ & $\begin{array}{l}0.0082 \\
(0.0142)\end{array}$ & & & & & \\
\hline $\begin{array}{l}\text { Pachylaelaps } \\
\text { karawaiewi }\end{array}$ & Prmi & & & & & $\begin{array}{l}0.0011 \\
(0.0019)\end{array}$ & & $\begin{array}{l}0.0141 \\
(0.0082)\end{array}$ & \\
\hline Pergamasus & Prmi & & & & $\begin{array}{l}0.0008 \\
(0.0014)\end{array}$ & & & $\begin{array}{l}0.0021 \\
(0.0036)\end{array}$ & $\begin{array}{l}0.0014 \\
(0.0025)\end{array}$ \\
\hline $\begin{array}{l}\text { Pergamasus } \\
\text { norvegicus }\end{array}$ & Prmi & $\begin{array}{l}0.0019 \\
(0.0034)\end{array}$ & & & & & & & \\
\hline Prozercon & Nemi & & & & $\begin{array}{l}0.0007 \\
(0.0008)\end{array}$ & & & $\begin{array}{l}0.0004 \\
(0.0007)\end{array}$ & \\
\hline Rhodacarellus & Prmi & & & & & & $\begin{array}{l}0.0006 \\
(0.001)\end{array}$ & $\begin{array}{l}0.0046 \\
(0.0041)\end{array}$ & \\
\hline $\begin{array}{l}\text { Rhodacarellus } \\
\text { silesiacus }\end{array}$ & Prmi & & & & & & & $\begin{array}{l}0.0045 \\
(0.0078)\end{array}$ & $\begin{array}{l}0.0115 \\
(0.0014)\end{array}$ \\
\hline Rhodacaridae & Prmi & & & & $\begin{array}{l}0.0011 \\
(0.002)\end{array}$ & & & & \\
\hline Uropoda & Prmi & & & & & & & & $\begin{array}{l}0.0074 \\
(0.0029)\end{array}$ \\
\hline $\begin{array}{l}\text { Uropoda } \\
\text { orbicularis }\end{array}$ & Prmi & & $\begin{array}{l}0.001 \\
(0.0017)\end{array}$ & & & & & & \\
\hline $\begin{array}{l}\text { Veigaia } \\
\text { nemorensis }\end{array}$ & Prmi & & & & $\begin{array}{l}0.0011 \\
(0.002)\end{array}$ & & & & \\
\hline $\begin{array}{l}\text { Veigaia plani- } \\
\text { cola }\end{array}$ & Prmi & & & & & & & & $\begin{array}{l}0.0013 \\
(0.0022)\end{array}$ \\
\hline $\begin{array}{l}\text { Oribatida } \\
\text { Liebstadia } \\
\text { similis }\end{array}$ & HFmi & & & & $\begin{array}{l}0.0001 \\
(0.0001)\end{array}$ & & & & \\
\hline
\end{tabular}


Table A1. Continued.

\begin{tabular}{|c|c|c|c|c|c|c|c|c|c|}
\hline Country & & Iceland & Iceland & Iceland & Iceland & Austria & Austria & Austria & Austria \\
\hline Type & & Conventional & Organic & Conventional & Organic & Conventional & Organic & Conventional & Organic \\
\hline Farm & & IceHaAcon & IceHaAorg & IceHiAcon & IceHiAorg & AusPOTcon & AusPOTorg & AusWWcon & \\
\hline Liochthonius & HFmi & & & & & & & & $\begin{array}{l}0.0003 \\
(0.0005)\end{array}$ \\
\hline $\begin{array}{l}\text { Liochthonius } \\
\text { propinquus }\end{array}$ & HFmi & & & & & & & & $\begin{array}{l}0.0008 \\
(0.0014)\end{array}$ \\
\hline Microppia minus & Fumi & & & & & $\begin{array}{l}0.0001 \\
(0.0002)\end{array}$ & & & \\
\hline $\begin{array}{l}\text { Oromurcia sudet- } \\
\text { ica }\end{array}$ & HFmi & & & & $\begin{array}{l}0.0014 \\
(0.0009)\end{array}$ & & & & \\
\hline $\begin{array}{l}\text { Pantelozetes } \\
\text { paolii }\end{array}$ & Fumi & $\begin{array}{l}0.0005 \\
(0.0004)\end{array}$ & $\begin{array}{l}0.0001 \\
(0.0002)\end{array}$ & & $\begin{array}{l}0.0002 \\
(0.0003)\end{array}$ & & & & \\
\hline $\begin{array}{l}\text { Platynothrus } \\
\text { thori }\end{array}$ & HFmi & & & $\begin{array}{l}0.0009 \\
(0.0016)\end{array}$ & & & & & \\
\hline $\begin{array}{l}\text { Protoribates } \\
\text { capucinus }\end{array}$ & Fumi & & & & & & & $\begin{array}{l}0.0008 \\
(0.0008)\end{array}$ & \\
\hline Rhysotritia ardua & HFmi & & & & & & & $\begin{array}{l}0.0003 \\
(0.0004)\end{array}$ & $\begin{array}{l}0.0006 \\
(0.0006)\end{array}$ \\
\hline $\begin{array}{l}\text { Tectocepheus ve- } \\
\text { latus }\end{array}$ & Ommi & & & & & $\begin{array}{l}0.001 \\
(0.0018)\end{array}$ & $\begin{array}{l}0.0009 \\
(0.0008)\end{array}$ & $\begin{array}{l}0.0046 \\
(0.004)\end{array}$ & $\begin{array}{l}0.0049 \\
(0.0043)\end{array}$ \\
\hline $\begin{array}{l}\text { Trhypochthonius } \\
\text { cladonicola }\end{array}$ & Ommi & & & & $\begin{array}{l}0.0084 \\
(0.0022)\end{array}$ & & & & \\
\hline Prostigmata & Ommi & 0.0018 & 0.0018 & 0.0027 & 0.0102 & 0.0018 & 0.0008 & 0.0569 & 0.0081 \\
\hline $\begin{array}{l}\text { Eupodes } \\
\text { Microtydeus }\end{array}$ & Ommi & $\begin{array}{l}(0.0019) \\
0.0002 \\
(0.0003)\end{array}$ & $\begin{array}{l}(0.0012) \\
0.001 \\
(0.0018)\end{array}$ & $(0.0047)$ & $\begin{array}{l}(0.0044) \\
0.0013 \\
(0.0017)\end{array}$ & $(0.0012)$ & $\begin{array}{l}(0.0003) \\
0.0003 \\
(0.0003)\end{array}$ & $\begin{array}{l}(0.0201) \\
0.0088 \\
(0.0009\end{array}$ & $\begin{array}{l}(0.0065) \\
0.0033 \\
(0.0057)\end{array}$ \\
\hline Nanorchestes & Ommi & & & & & $\begin{array}{l}0.0539 \\
(0.0506)\end{array}$ & $\begin{array}{l}0.0143 \\
(0.0062)\end{array}$ & $\begin{array}{l}0.0909 \\
(0.0206)\end{array}$ & $\begin{array}{l}0.0229 \\
(0.0032)\end{array}$ \\
\hline Pyemotes & Prmi & & & & $\begin{array}{l}0.0023 \\
(0.0024)\end{array}$ & & & & \\
\hline Pygmephorus & Fumi & $\begin{array}{l}0.0001 \\
(0.0002)\end{array}$ & $\begin{array}{l}0.001 \\
(0.001)\end{array}$ & $\begin{array}{l}0.0039 \\
(0.0034)\end{array}$ & $\begin{array}{l}0.0025 \\
(0.0028)\end{array}$ & $\begin{array}{l}0.0012 \\
(0.0014)\end{array}$ & $\begin{array}{l}0.0006 \\
(0.0005)\end{array}$ & $\begin{array}{l}0.0079 \\
(0.0075)\end{array}$ & $\begin{array}{l}0.004 \\
(0.0021)\end{array}$ \\
\hline Rhagidia & Prmi & & & & $\begin{array}{l}0.0028 \\
(0.0025)\end{array}$ & $\begin{array}{l}0.0035 \\
(0.0049)\end{array}$ & & $\begin{array}{l}0.0021 \\
(0.0036)\end{array}$ & \\
\hline Scutacarus & Ommi & & & & $\begin{array}{l}0.0016 \\
(0.0015)\end{array}$ & $\begin{array}{l}0.0007 \\
(0.0012)\end{array}$ & $\begin{array}{l}0.0002 \\
(0.0003)\end{array}$ & & \\
\hline Speleorchestes & Ommi & & & & & $\begin{array}{l}0.0095 \\
(0.0029)\end{array}$ & $\begin{array}{l}0.009 \\
(0.0029)\end{array}$ & $\begin{array}{l}0.0037 \\
(0.0025)\end{array}$ & $\begin{array}{l}0.0004 \\
(0.0007)\end{array}$ \\
\hline Stigmaeidae & Prmi & & & $\begin{array}{l}0.0432 \\
(0.0549)\end{array}$ & & & & & \\
\hline Tarsonemus & Ommi & & & $\begin{array}{l}0.004 \\
(0.004)\end{array}$ & $\begin{array}{l}0.0016 \\
(0.0015)\end{array}$ & & & & \\
\hline Trombidiidae & Prmi & & & & & & & & $\begin{array}{l}0.0013 \\
(0.0022)\end{array}$ \\
\hline Tydeidae & Ommi & & & $\begin{array}{l}0.0083 \\
(0.0084)\end{array}$ & $\begin{array}{l}0.0007 \\
(0.0007)\end{array}$ & & & & \\
\hline Collembola & & & & & & & & & \\
\hline Entomobryomorpha & HFco & $\begin{array}{l}0.0066 \\
(0.0026)\end{array}$ & & $\begin{array}{l}0.1007 \\
(0.1064)\end{array}$ & $\begin{array}{l}0.0089 \\
(0.0035)\end{array}$ & & & & \\
\hline $\begin{array}{l}\text { Folsomia sex- } \\
\text { oculata }\end{array}$ & & & & & & & & & \\
\hline $\begin{array}{l}\text { Folsomides } \\
\text { parvulus }\end{array}$ & Fuco & & & & & & $\begin{array}{l}0.0006 \\
(0.0011)\end{array}$ & & $\begin{array}{l}0.0015 \\
(0.0026)\end{array}$ \\
\hline Isotoma & Fuco & & $\begin{array}{l}0.0006 \\
(0.001)\end{array}$ & & $\begin{array}{l}0.0048 \\
(0.0083)\end{array}$ & & & & \\
\hline $\begin{array}{l}\text { Isotoma angli- } \\
\text { cana }\end{array}$ & Fuco & & & $\begin{array}{l}0.0045 \\
(0.0078)\end{array}$ & $\begin{array}{l}0.0009 \\
(0.0015)\end{array}$ & & & & \\
\hline Isotomiella minor & Fuco & $\begin{array}{l}0.0006 \\
(0.0011)\end{array}$ & $\begin{array}{l}0.0056 \\
(0.0038)\end{array}$ & $\begin{array}{l}0.0416 \\
(0.0607)\end{array}$ & $\begin{array}{l}0.0307 \\
(0.0226)\end{array}$ & $\begin{array}{l}0.0032 \\
(0.0017)\end{array}$ & $\begin{array}{l}0.0005 \\
(0.0009)\end{array}$ & & \\
\hline Lepidocyrtus & HFco & & & & & & & $\begin{array}{l}0.0054 \\
(0.0094)\end{array}$ & \\
\hline $\begin{array}{l}\text { Lepidocyrtus cya- } \\
\text { neus }\end{array}$ & HFco & & & & & $\begin{array}{l}0.008 \\
(0.0097)\end{array}$ & $\begin{array}{l}0.0006 \\
(0.0011)\end{array}$ & & $\begin{array}{l}0.0014 \\
(0.0024)\end{array}$ \\
\hline $\begin{array}{l}\text { Parisotoma nota- } \\
\text { bilis }\end{array}$ & Fuco & & & $\begin{array}{l}0.0371 \\
(0.0643)\end{array}$ & $\begin{array}{l}0.0366 \\
(0.0434)\end{array}$ & $\begin{array}{l}0.0068 \\
(0.0118)\end{array}$ & $\begin{array}{l}0.0042 \\
(0.0046)\end{array}$ & $\begin{array}{l}0.0219 \\
(0.0022)\end{array}$ & $\begin{array}{l}0.0221 \\
(0.0093)\end{array}$ \\
\hline $\begin{array}{l}\text { Proisotoma min- } \\
\text { uta }\end{array}$ & Fuco & & & & & $\begin{array}{l}0.0364 \\
(0.0631)\end{array}$ & & & $\begin{array}{l}0.0338 \\
(0.0024)\end{array}$ \\
\hline $\begin{array}{l}\text { Pseudisotoma } \\
\text { sensibilis }\end{array}$ & Fuco & & & & & & & & $\begin{array}{l}0.0036 \\
(0.0062)\end{array}$ \\
\hline $\begin{array}{l}\text { Pseudosinella } \\
\text { alba }\end{array}$ & HFco & & & & & & $\begin{array}{l}0.0012 \\
(0.0021)\end{array}$ & $\begin{array}{l}0.0024 \\
(0.0041)\end{array}$ & $\begin{array}{l}0.0051 \\
(0.0054)\end{array}$ \\
\hline $\begin{array}{l}\text { Neelipleona } \\
\text { Megalothorax } \\
\text { minimus }\end{array}$ & HFco & & & & & $\begin{array}{l}0.0016 \\
(0.0017)\end{array}$ & $\begin{array}{l}0.0012 \\
(0.0021)\end{array}$ & $\begin{array}{l}0.0027 \\
(0.0047)\end{array}$ & $\begin{array}{l}0.0051 \\
(0.0054)\end{array}$ \\
\hline $\begin{array}{l}\text { Poduromorpha } \\
\text { Ceratophysella } \\
\text { denticulata }\end{array}$ & Fuco & $\begin{array}{l}0.0952 \\
(0.0525)\end{array}$ & $\begin{array}{l}0.0414 \\
(0.0481)\end{array}$ & $\begin{array}{l}0.2088 \\
(0.092)\end{array}$ & $\begin{array}{l}0.0017 \\
(0.003)\end{array}$ & & $\begin{array}{l}0.0105 \\
(0.0167)\end{array}$ & $\begin{array}{l}0.0024 \\
(0.0041)\end{array}$ & $\begin{array}{l}0.0959 \\
(0.0284)\end{array}$ \\
\hline Friesea truncata & Fuco & $\begin{array}{l}0.0006 \\
(0.0011)\end{array}$ & $\begin{array}{l}0.0024 \\
(0.0041)\end{array}$ & & $\begin{array}{l}0.0077 \\
(0.0073)\end{array}$ & & & & \\
\hline Hypogastrura & Fuco & & & & & & & $\begin{array}{l}0.01 \\
(0.0054)\end{array}$ & \\
\hline Mesaphorura & Fuco & & & $\begin{array}{l}0.0132 \\
(0.0131)\end{array}$ & & & & & \\
\hline
\end{tabular}


Table A1. Continued.

\begin{tabular}{|c|c|c|c|c|c|c|c|c|c|}
\hline Country & & Iceland & Iceland & Iceland & Iceland & Austria & Austria & Austria & Austria \\
\hline $\begin{array}{l}\text { Type } \\
\text { Farm }\end{array}$ & & $\begin{array}{l}\text { Conventional } \\
\text { IceHaAcon }\end{array}$ & $\begin{array}{l}\text { Organic } \\
\text { IceHaAorg }\end{array}$ & $\begin{array}{l}\text { Conventional } \\
\text { IceHiAcon }\end{array}$ & $\begin{array}{l}\text { Organic } \\
\text { IceHiAorg }\end{array}$ & $\begin{array}{l}\text { Conventional } \\
\text { AusPOTcon }\end{array}$ & $\begin{array}{l}\text { Organic } \\
\text { AusPOTorg }\end{array}$ & $\begin{array}{l}\text { Conventional } \\
\text { AusWWcon }\end{array}$ & $\begin{array}{l}\text { Organic } \\
\text { AusWWorg }\end{array}$ \\
\hline $\begin{array}{l}\text { Mesaphorura } \\
\text { macrochaeta }\end{array}$ & Fuco & & & & & & $\begin{array}{l}0.0032 \\
(0.0031)\end{array}$ & & $\begin{array}{l}0.0183 \\
(0.0081)\end{array}$ \\
\hline Onychiurus & Fuco & $\begin{array}{l}0.0376 \\
(0.0219)\end{array}$ & $\begin{array}{l}0.0079 \\
(0.0107)\end{array}$ & & $\begin{array}{l}0.0139 \\
(0.0072)\end{array}$ & $\begin{array}{l}0.0046 \\
(0.0079)\end{array}$ & $\begin{array}{l}0.0012 \\
(0.0021)\end{array}$ & & \\
\hline $\begin{array}{l}\text { Paratullbergia } \\
\text { callipygos }\end{array}$ & Fuco & & & & & & & & $\begin{array}{l}0.0015 \\
(0.0026)\end{array}$ \\
\hline $\begin{array}{l}\text { Stenaphorurella } \\
\text { quadrispina }\end{array}$ & Fuco & & & & & & & & $\begin{array}{l}0.0036 \\
(0.0062)\end{array}$ \\
\hline Tullbergia & HFco & $\begin{array}{l}0.0027 \\
(0.0032)\end{array}$ & & & & & & & \\
\hline Symphypleona & Heco & $\begin{array}{l}0.0196 \\
(0.0271)\end{array}$ & & $\begin{array}{l}0.0045 \\
(0.0078)\end{array}$ & $\begin{array}{l}0.0023 \\
(0.0022)\end{array}$ & $\begin{array}{l}0.0034 \\
(0.0059)\end{array}$ & & $\begin{array}{l}0.0024 \\
(0.0041)\end{array}$ & \\
\hline $\begin{array}{l}\text { Sminthuridae } \\
\text { Sminthurinus }\end{array}$ & Heco & & $\begin{array}{l}0.0173 \\
(0.0155)\end{array}$ & & & & & & \\
\hline $\begin{array}{l}\text { Sminthurus } \\
\text { viridis }\end{array}$ & Heco & & & & & $\begin{array}{l}0.011 \\
(0.0121)\end{array}$ & $\begin{array}{l}0.0011 \\
(0.001)\end{array}$ & & \\
\hline $\begin{array}{l}\text { Sphaeridia } \\
\text { pumilis }\end{array}$ & Heco & & $\begin{array}{l}0.017 \\
(0.007)\end{array}$ & $\begin{array}{l}0.0186 \\
(0.0321)\end{array}$ & $\begin{array}{l}0.0014 \\
(0.0025)\end{array}$ & & & & \\
\hline Diplura & Dipl & & & & & & & $\begin{array}{l}0.0024 \\
(0.0041)\end{array}$ & \\
\hline Pauropoda & Fuco & & & & $\begin{array}{l}0.016 \\
(0.0163)\end{array}$ & $\begin{array}{l}0.0011 \\
(0.002)\end{array}$ & $\begin{array}{l}0.0006 \\
(0.001)\end{array}$ & $\begin{array}{l}0.0048 \\
(0.0083)\end{array}$ & $\begin{array}{l}0.0078 \\
(0.0031)\end{array}$ \\
\hline
\end{tabular}


Acknowledgements. This research was funded by the EU FP7ENV-2009 project SoilTrEC "Soil Transformations in European Catchments" (contract no. 244118). This research was also supported by the research programme KB IV "Innovative scientific research for sustainable green and blue environment" funded by the Netherlands Ministry of Economic Affairs, Agriculture and Innovation, and carried out by Wageningen University and Research Centre.

We thank An Vos, Meint Veninga, Popko Bolhuis, and Tamas Salanki for technical assistance. Wim Dimmers and Gerard Jagers are acknowledged for counting and identifying microarthropods. We are grateful to the farmers for access to their land, and for providing land management information.

Edited by: S. Grandy

\section{References}

Altieri, M. A.: The ecological role of biodiversity in agroecosystems, Agr. Ecosyst. Environ., 74, 19-31, 1999.

Anderson, J.: Inter-and intra-habitat relationships between woodland cryptostigmata species diversity and the diversity of soil and litter microhabitats, Oecologia, 32, 341-348, 1978.

Anderson, S. P., Bales, R. C., and Duffy, C. J.: Critical zone observatories: Building a network to advance interdisciplinary study of earth surface processes, Mineral. Mag., 72, 7-10, 2008.

Banwart, S., Bernasconi, S. M., Bloem, J., Blum, W., Brandao, M., Brantley, S., Chabaux, F., Duffy, C., Kram, P., Lair, G., Lundin, L., Nikolaidis, N., Novak, M., Panagos, P., Ragnarsdottir, K. V., Reynolds, B., Rousseva, S., de Ruiter, P., van Gaans, P., van Riemsdijk, W., White, T., and Zhang, B.: Soil processes and functions in critical zone observatories: Hypotheses and experimental design, Vadose Zone J., 10, 974-987, doi:10.2136/vzj2010.0136, 2011.

Bardgett, R. D., Frankland, J. C., and Whittaker, J. B.: The effects of agricultural management on the soil biota of some upland grasslands, Agr. Ecosyst. Environ., 45, 25-45, 1993.

Barrios, E.: Soil biota, ecosystem services and land productivity, Ecol. Econom., 64, 269-285, doi:10.1016/j.ecolecon.2007.03.004, 2007.

Beare, M. H., Hendrix, P. F., and Coleman, D. C.: Waterstable aggregates and organic matter fractions in conventionaland no-tillage soils, Soil Sci. Soc. Am. J., 58, 777-786, doi:10.2136/sssaj1994.03615995005800030020x, 1994.

Beare, M. H., Hu, S., Coleman, D., and Hendrix, P.: Influences of mycelial fungi on soil aggregation and organic matter storage in conventional and no-tillage soils, Appl. Soil Ecol., 5, 211-219, 1997.

Bernasconi, S. M., Bauder, A., Bourdon, B., Brunner, I., Bünemann, E., Chris, I., Derungs, N., Edwards, P., Farinotti, D., and Frey, B.: Chemical and biological gradients along the damma glacier soil chronosequence, Switzerland, Vadose Zone J., 10, 867-883, 2011.

Birkhofer, K., Bezemer, M. T., Bloem, J., Bonkowski, M., Christensen, S., Dubois, D., Ekelund, F., Fließbach, A., Gunst, L., and Hedlund, K.: Long-term organic farming fosters below and aboveground biota: Implications for soil quality, biological control and productivity, Soil Biol. Biochem., 40, 2297-2308, 2008.
Bloem, J., Lebbink, G., Zwart, K. B., Bouwman, L. A., Burgers, S. L. G. E., de Vos, J. A., and de Ruiter, P. C.: Dynamics of microorganisms, microbivores and nitrogen mineralization in winter-wheat fields under conventional and integrated management, Agr. Ecosyst. Environ., 51, 129-143, doi:10.1016/01678809(94)90039-6, 1994.

Bloem, J. and Vos, A.: Fluorescent staining of microbes for total direct counts, in: Molecular microbial ecology manual,edited by: Kowalchuk, G. A., de Bruijn, F. J., Head, I. M., Akkermans, A. D. L., and van Elsas, J. D., Kluwer Academic Publishers, Dordrecht, 2nd Edn., 861-874, 2004.

Bloem, J., Veninga, M., and Shepherd, J.: Fully automatic determination of soil bacterium numbers, cell volumes, and frequencies of dividing cells by confocal laser scanning microscopy and image analysis, Appl. Environ. Microbiol., 61, 926-936, 1995.

Bloem, J. and Bolhuis, P. R.: Thymidine and leucine incorporation to assess bacterial growth rate, in: Microbiological methods for assessing soil quality, edited by: Bloem, J., Hopkins, D. W., and Benedetti, A., CABI Publishing, Wallingford, UK, Cambridge, MA, 142-149, 2006.

Bloem, J., Schouten, A. J., Sørensen, S. J., Rutgers, M., van der Werf, A., and Breure, A. M.: Monitoring and evaluating soil quality, in: Microbiological methods for assessing soil quality, edited by: Bloem, J., Hopkins, D. W., and Benedetti, A., CABI Publishing, Wallingford, UK, 23-49, 2006.

Bongers, T.: De nematoden van Nederland: Een identificatietabel voor de in Nederland aangetroffen zoetwater-en bodembewonende nematoden, Koninklijke Nederlandse Natuurhistorische Vereiniging, 1988.

Burt, R.: Soil survey laboratory methods manual, USDA, 1992.

Canali, S. and Benedetti, A.: Soil nitrogen mineralization, in: Microbiological methods for assessing soil quality, edited by: Bloem, J., Hopkins, D. W., and Benedetti, A., CABI Publishing, Wallingford, UK, 127-135, 2006.

Costanza, R., d'Arge, R., de Groot, R., Farber, S., Grasso, M., Hannon, B., Limburg, K., Naeem, S., O’Neill, R. V., and Paruelo, J.: The value of the world's ecosystem services and natural capital, Nature, 387, 253-260, 1997.

de Gryze, S., Six, J., Brits, C., and Merckx, R.: A quantification of short-term macroaggregate dynamics: Influences of wheat residue input and texture, Soil Biol. Biochem., 37, 55-66, doi:10.1016/j.soilbio.2004.07.024, 2005.

de Ruiter, P. C., Neutel, A.-M., and Moore, J. C.: Modelling food webs and nutrient cycling in agro-ecosystems, Trends Ecol. Evolut., 9, 378-383, 1994.

de Vries, F. T., Hoffland, E., van Eekeren, N., Brussaard, L., and Bloem, J.: Fungal/bacterial ratios in grasslands with contrasting nitrogen management, Soil Biol. Biochem., 38, 2092-2103, 2006.

Didden, W. A. M., Marinissen, J. C. Y., Vreekenbuijs, M. J., Burgers, S., de Fluiter, R., Geurs, M., and Brussaard, L.: Soil mesofauna and macrofauna in 2 agricultural systems - factors affecting population-dynamics and evaluation of their role in carbon and nitrogen dynamics, Agr. Ecosyst. Environ., 51, 171-186, 1994.

Doles, J. L., Zimmerman, R. J., and Moore, J. C.: Soil microarthropod community structure and dynamics in organic and conventionally managed apple orchards in western Colorado, USA, Appl. Soil Ecol., 18, 83-96, 2001. 
Gardi, C. and Parisi, V.: Use of microarthropods as biological indicators of soil quality: The bsq sinthetic indicator, 7. International Meeting on: Soils with Mediterranean Type of Climate, Valenzano (Italy), 23-28 September 2001, 2002.

Gardi, C., Montanarella, L., Arrouays, D., Bispo, A., Lemanceau, P., Jolivet, C., Mulder, C., Ranjard, L., Römbke, J., and Rutgers, M.: Soil biodiversity monitoring in Europe: Ongoing activities and challenges, Euro. J. Soil Sci., 60, 807-819, 2009.

Ghani, A., Dexter, M., and Perrott, K. W.: Hot-water extractable carbon in soils: A sensitive measurement for determining impacts of fertilisation, grazing and cultivation, Soil Biol. Biochem., 35, 1231-1243, doi:10.1016/s0038-0717(03)00186-x, 2003.

Golchin, A., Oades, J., Skjemstad, J., and Clarke, P.: Soil structure and carbon cycling, Soil Research, 32, 1043-1068, 1994.

Griffiths, B. S., Ritz, K., Bardgett, R. D., Cook, R., Christensen, S., Ekelund, F., Sørensen, S. J., Bååth, E., Bloem, J., and de Ruiter, P. C.: Ecosystem response of pasture soil communities to fumigation-induced microbial diversity reductions: An examination of the biodiversity-ecosystem function relationship, Oikos, 90, 279-294, 2000.

Gunapala, N. and Scow, K. M.: Dynamics of soil microbial biomass and activity in conventional and organic farming systems, Soil Biol. Biochem., 30, 805-816, doi:10.1016/S00380717(97)00162-4, 1998.

Hansen, R. A. and Coleman, D. C.: Litter complexity and composition are determinants of the diversity and species composition of oribatid mites (acari: Oribatida) in litterbags, Appl. Soil Ecol., 9, 17-23, 1998.

Haubert, D., Birkhofer, K., Fliessbach, A., Gehre, M., Scheu, S., and Ruess, L.: Trophic structure and major trophic links in conventional versus organic farming systems as indicated by carbon stable isotope ratios of fatty acids, Oikos, 118, 1579-1589, 2009.

Hole, D. G., Perkins, A. J., Wilson, J. D., Alexander, I. H., Grice, P. V., and Evans, A. D.: Does organic farming benefit biodiversity?, Biol. Conserv., 122, 113-130, 2005.

Jagers op Akkerhuis, G. A. J. M., Dimmers, W. J., van Vliet, P. C. J., Goedhart, P. W., Martakis, G. F. P., and de Goede, R. G. M.: Evaluating the use of gel-based sub-sampling for assessing responses of terrestrial microarthropods (collembola and acari) to different slurry applications and organic matter contents, Appl. Soil Ecol., 38, 239-248, 2008.

Jastrow, J. D. and Miller, R. M.: Methods for assessing the effects of biota on soil structure, Agr. Ecosyst. Environ., 34, 279-303, doi:10.1016/0167-8809(91)90115-E, 1991.

Kemper, W. D. and Rosenau, R. C.: Aggregate stability and size distribution, in: Methods of Soil Analysis. Part 1. Physical and Mineralogical Methods, edited by: Klute, A., Agronomy Monograph 9, 2nd Edn., ASA/SSSA, Madison, WI, USA, 425-442, 1986.

Kent, M. and Coker, P.: Vegetation description and analysis: A practical approach, London, UK, John Wiley and Sons, X, 1992.

Lavelle, P., Decaëns, T., Aubert, M., Barot, S., Blouin, M., Bureau, F., Margerie, P., Mora, P., and Rossi, J. P.: Soil invertebrates and ecosystem services, Euro. J. Soil Biol., 42, Supplement 1, S3-S15, doi:10.1016/j.ejsobi.2006.10.002, 2006.

Lee, K. E. and Foster, R. C.: Soil fauna and soil structure, Soil Research, 29, 745-775, 1991.

Lehtinen, T., Lair, G. J., Mentler, A., Gísladóttir, G., Ragnarsdóttir, K. V., and Blum, W. E. H.: Soil aggregate stabil- ity in different soil orders quantified by low dispersive ultrasonic energy levels, Soil Sci. Soc. Am. J., 78, 713-723, doi:10.2136/sssaj2013.02.0073, 2014.

Macfadyen, S., Gibson, R., Polaszek, A., Morris, R. J., Craze, P. G., Planqué, R., Symondson, W. O. C., and Memmott, J.: Do differences in food web structure between organic and conventional farms affect the ecosystem service of pest control?, Ecol. Lett., 12, 229-238, 2009.

Mäder, P., Fliessbach, A., Dubois, D., Gunst, L., Fried, P., and Niggli, U.: Soil fertility and biodiversity in organic farming, Science, 296, 1694-1697, 2002.

Menon, M., Rousseva, S., Nikolaidis, N. P., van Gaans, P., Panagos, P., de Souza, D. M., Ragnarsdottir, K. V., Lair, G. J., Weng, L., and Bloem, J.: Soiltrec: A global initiative on critical zone research and integration, Environ. Sci. Pollut. Res., 21, 3191-3195, 2014.

Moore, J. C., Walter, D. E., and Hunt, H. W.: Arthropod regulation of micro-and mesobiota in below-ground detrital food webs, Ann. Rev. Entomol., 33, 419-435, 1988.

Oades, J. M.: The role of biology in the formation, stabilization and degradation of soil structure, Geoderma, 56, 377-400, doi:10.1016/0016-7061(93)90123-3, 1993.

Parisi, V., Menta, C., Gardi, C., Jacomini, C., and Mozzanica, E.: Microarthropod communities as a tool to assess soil quality and biodiversity: A new approach in Italy, Agr. Ecosyst. Environ., 105, 323-333, 2005.

Pattison, A. B., Moody, P. W., Badcock, K. A., Smith, L. J., Armour, J. A., Rasiah, V., Cobon, J. A., Gulino, L. M., and Mayer, R.: Development of key soil health indicators for the Australian banana industry, Appl. Soil Ecol., 40, 155-164, doi:10.1016/j.apsoil.2008.04.002, 2008.

Ponge, J.-F., Dubs, F., Gillet, S., Sousa, J. P., and Lavelle, P.: Decreased biodiversity in soil springtail communities: The importance of dispersal and landuse history in heterogeneous landscapes, Soil Biol. Biochem., 38, 1158-1161, doi:10.1016/j.soilbio.2005.09.004, 2006.

Poudel, D. D., Horwath, W. R., Lanini, W. T., Temple, S. R., and Van Bruggen, A. H. C.: Comparison of soil $\mathrm{N}$ availability and leaching potential, crop yields and weeds in organic, low-input and conventional farming systems in northern California, Agr. Ecosyst. Environ., 90, 125-137, 2002.

Ritz, K., Black, H. I., Campbell, C. D., Harris, J. A., and Wood, C.: Selecting biological indicators for monitoring soils: A framework for balancing scientific and technical opinion to assist policy development, Ecol. Indic., 9, 1212-1221, 2009.

Setälä, H., Berg, M. P., and Jones, T. H.: Trophic structure and functional redundancy in soil communities, Biological diversity and function in soils, 236-249, 2005.

Shannon, D., Sen, A., and Johnson, D.: A comparative study of the microbiology of soils managed under organic and conventional regimes, Soil Use Manage., 18, 274-283, 2002.

Siepel, H. and Van de Bund, C.: The influence of management practises on the microarthropod community of grassland, Pedobiologia, 31, 339-354, 1988.

Six, J., Paustian, K., Elliott, E., and Combrink, C.: Soil structure and organic matter i. Distribution of aggregate-size classes and aggregate-associated carbon, Soil Sci. Soc. Am. J., 64, 681-689, 2000 . 
Sjursen, H., Michelsen, A., and Holmstrup, M.: Effects of freeze-thaw cycles on microarthropods and nutrient availability in a sub-arctic soil, Appl. Soil Ecol., 28, 79-93, doi:10.1016/j.apsoil.2004.06.003, 2005.

Skinner, J., Lewis, K., Bardon, K., Tucker, P., Catt, J., and Chambers, B.: An overview of the environmental impact of agriculture in the uk, J. Environ. Manage., 50, 111-128, 1997.

Steffens, M., Kölbl, A., and Kögel-Knabner, I.: Alteration of soil organic matter pools and aggregation in semi-arid steppe topsoils as driven by organic matter input, Euro. J. Soil Sci., 60, 198-212, 2009.

Sulkava, P. and Huhta, V.: Habitat patchiness affects decomposition and faunal diversity: A microcosm experiment on forest floor, Oecologia, 116, 390-396, 1998.

Tisdall, J. and Oades, J. M.: Organic matter and water-stable aggregates in soils, J. Soil Sci., 33, 141-163, 1982.

van Diepeningen, A. D., de Vos, O. J., Korthals, G. W., and van Bruggen, A. H.: Effects of organic versus conventional management on chemical and biological parameters in agricultural soils, Appl. Soil Ecol., 31, 120-135, 2006.

van Eekeren, N., de Boer, H., Bloem, J., Schouten, T., Rutgers, M., de Goede, R., and Brussaard, L.: Soil biological quality of grassland fertilized with adjusted cattle manure slurries in comparison with organic and inorganic fertilizers, Biol. Fert. Soils, 45, 595608,2009
Vitousek, P. M.: Human domination of earth's ecosystems, Science, 277, 494-499, 1997.

Vreeken-Buijs, M. J., Hassink, J., and Brussaard, L.: Relationships of soil microarthropod biomass with organic matter and pore size distribution in soils under different land use, Soil Biol. Biochem., 30, 97-106, 1998.

Wardle, D. A., Begon, M., and Fitter, A. H.: Impacts of disturbance on detritus food webs in agro-ecosystems of contrasting tillage and weed management practices, in: Advances in ecological research, Academic Press, 105-185, 1995.

Wardle, D. A., Bardgett, R. D., Klironomos, J. N., Setala, H., van der Putten, W. H., and Wall, D. H.: Ecological linkages between aboveground and belowground biota, Science, 304, 1629-1633, 2004.

Wardle, D. A., Bardgett, R. D., Usher, M. B., and Hopkins, D. W.: How plant communities influence decomposer communities, Biological diversity and function in soils, 119-138, 2005.

Wright, S. F., Green, V. S., and Cavigelli, M. A.: Glomalin in aggregate size classes from three different farming systems, Soil Till. Res., 94, 546-549, doi:10.1016/j.still.2006.08.003, 2007.

Yeates, G. W., Bardgett, R. D., Cook, R., Hobbs, P. J., Bowling, P. J., and Potter, J. F.: Faunal and microbial diversity in three welsh grassland soils under conventional and organic management regimes, J. Appl. Ecol., 34, 453-470, 1997. 